No. 16

MAYO DE 2016

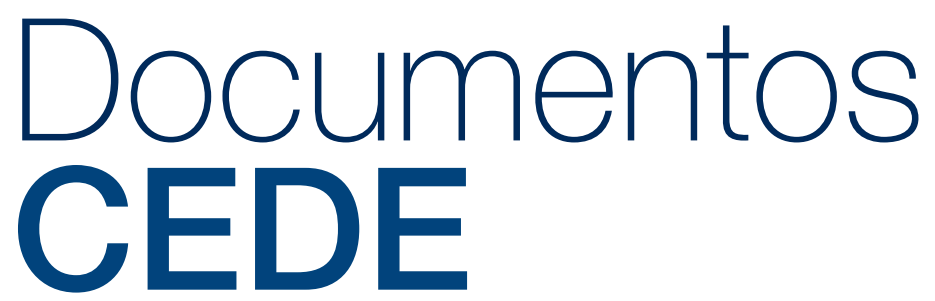

ISSN 1657-7191 Edición electrónica.

The Influence of Multilateral

Development Institutions on Latin American Development Strategies

Guillermo Perry Eduardo Garcia 


\section{CEDE}

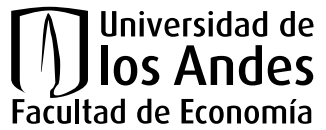

Serie Documentos Cede, 2016-16

ISSN 1657-7191 Edición electrónica.

Mayo de 2016

(C) 2016, Universidad de los Andes, Facultad de Economía, CEDE. Calle 19A No. 1 - 37 Este, Bloque W.

Bogotá, D. C., Colombia Teléfonos: 3394949- 3394999, extensiones 2400, 2049, 3233

infocede@uniandes.edu.co

http://economia.uniandes.edu.co

Impreso en Colombia - Printed in Colombia

La serie de Documentos de Trabajo CEDE se circula con propósitos de discusión y divulgación. Los artículos no han sido evaluados por pares ni sujetos a ningún tipo de evaluación formal por parte del equipo de trabajo del CEDE.

El contenido de la presente publicación se encuentra protegido por las normas internacionales y nacionales vigentes sobre propiedad intelectual, por tanto su utilización, reproducción, comunicación pública, transformación, distribución, alquiler, préstamo público e importación, total o parcial, en todo o en parte, en formato impreso, digital o en cualquier formato conocido o por conocer, se encuentran prohibidos, y sólo serán lícitos en la medida en que se cuente con la autorización previa y expresa por escrito del autor o titular. Las limitaciones y excepciones al Derecho de Autor, sólo serán aplicables en la medida en que se den dentro de los denominados Usos Honrados (Fair use), estén previa y expresamente establecidas, no causen un grave e injustificado perjuicio a los intereses legítimos del autor o titular, y no atenten contra la normal explotación de la obra. 


\title{
The Influence of Multilateral Development Institutions on Latin American Development Strategies ${ }^{1}$
}

\author{
Special Issue of International Development Policy on Latin America \\ Guillermo Perry $^{2}$ \\ Eduardo García ${ }^{3}$
}

\begin{abstract}
This paper discusses the changing relation between Multilateral Development Institutions and Latin America, especially since the 1980s to the present. The paper first depicts how MDI's influence on LA has varied over time and across countries, depending on access to international private capital markets, the development of long-term markets for domestic currency government bonds, and the significant reduction of macro-financial vulnerabilities in the region. It then illustrates how MDI's views on macroeconomic and development policies has evolved over time, influenced by academic developments and also by Latin American governments. Finally, the paper shows how most governments in the region, whether left-wing or center-right oriented, have increasingly converged with MDI's recommendations on macrofinancial policies, while historically many, from all ends of the political spectrum, applied both macro and micro policies differing with MDI's views.
\end{abstract}

Keywords: Multilateral Development Institutions, Development Banks, Latin American development.

JEL Codes: F33, F34, N10.

\footnotetext{
${ }^{1}$ We would like to thank the Graduate Institute of Geneva for its generous underwriting and assistance. We would also like to thank Guilles Carbonnier, Theotonio do Santos and the other participants in the author's workshop of this Special Issue for their useful comments. Finally, we are very grateful to Alex Cantor from IFC and Rocío Casas from CAF who kindly helped us collecting the data.

2 Professor and researcher at the Faculty of Economics at Universidad de los Andes. Fellow researcher at the Center for Global Development, email: gperry@uniandes.edu.co

${ }^{3}$ Researcher at the Faculty of Economics at Universidad de los Andes, email: e.garcia916@uniandes.edu.co
} 


\title{
La influencia de las Instituciones Multilaterales de Crédito sobre las estrategias de desarrollo latinoamericanas ${ }^{4}$
}

\author{
Informe especial de política internacional de desarrollo sobre América Latina \\ Guillermo Perry $^{5}$ \\ Eduardo García ${ }^{6}$
}

\section{Resumen}

Este trabajo estudia la relación cambiante entre las Entidades Multilaterales de Desarrollo y América Latina, especialmente desde 1980 hasta la fecha. En primer lugar, explica cómo la influencia de las EMD sobre AL ha cambiado con el tiempo y entre países, dependiendo del acceso de éstos a los mercados internacionales de capitales, el desarrollo y profundidad de sus mercados internos para bonos gubernamentales y corporativos de largo plazo, y la significativa reducción en la vulnerabilidad macro-financiera de la región. Después examina cómo la visión de las EMD sobre políticas macroeconómicas y de desarrollo ha ido evolucionando, influenciada tanto por desarrollos académicos como por los gobiernos latinoamericanos. Finalmente, muestra cómo la mayoría de los gobiernos de la región, tanto de izquierda cómo de centro-derecha, han venido aplicando crecientemente políticas macro-financieras que coinciden con la visión de las EMD, mientras que históricamente muchos de ellos, con diversas orientaciones políticas, aplicaron políticas macro y micro que divergían de sus recomendaciones.

Palabras clave: Entidades Multilaterales de Crédito, Bancos de desarrollo, Desarrollo latinoamericano.

Códigos JEL: F33, F34, N10.

\footnotetext{
${ }^{4}$ Quisiéramos agradecer al Graduate Institute of Geneva por su generoso financiamiento y asesoría. También quisiéramos agradecer a Guilles Carbonnier, Theotonio do Santos y a los demás asistentes del taller de autores de este Special Issue por sus valiosos comentarios. Por último, estamos muy agradecidos con Alex Cantor de la IFC y con Rocío Casas de la CAF quienes amablemente nos colaboraron en la recolección de datos.

${ }^{5}$ Profesor e investigador de la facultad de economía de la Universidad de los Andes. Investigador asociado del Center for Global Development. Contacto: gperry@uniandes.edu.co

${ }^{6}$ Investigador de la facultad de economía de la Universidad de los Andes. Contacto: e.garcia916@uniandes.edu.co
} 


\section{Introduction}

The MDI's (specially the IMF and the WB) are frequently seen in Latin America as agencies that have imposed their 'neoliberal' or 'pro-market' views on countries in the region, following the interest of Northern countries and multinationals, and leading to persistent underdevelopment, poverty and inequality. On the other hand, some Latin American governments and technocrats have often seen them as useful allies in the pursuit of

modernizing reforms, sensible policies and contention of rent-seeking powerful domestic lobbies.

As with most stereotyped narratives, the true story normally lies somewhere between these extreme positions. Further, it has considerably evolved over time.

We begin by exploring, in Section 2 below, how MDI's influence in Latin America has varied over time and across countries, depending on their access to international and domestic private capital markets, among other factors. Section 3, then, illustrates how MDI's views on macroeconomic and development policies have changed over time, influenced mostly by evolving views in the international academic community, but also on occasions, by Latin American views and policy innovations. Section 4 discusses cases of both left-wing and centerright governments in Latin America that have followed strategies and implemented policies similar to those promoted by MDI's at the time, as well as some, from all ends of the political spectrum, that applied policies that were clearly at odds with current views in the MDI community. It shows how some of these were successful policy innovations, several of which were latter on embraced by the MDI's official positions, while others were clearly not successful. Section 5 concludes.

\section{The changing degree of influence of MDI's over time}

The degree of influence of MDI's on Latin American countries policies (as has been the case in other developing regions) has varied substantially across countries and over time, depending on the scarcity value of foreign exchange resources for individual beneficiary countries at any point in time. Governments in countries with good access to international 
capital markets, and/or deep domestic financial markets, have not needed to accept MDI advice in order to finance their developmental needs. On the other extreme, governments facing currency and fiscal crisis, and/or without access to either international or domestic private capital markets, have desperately needed MDI's financial resources and have had scarce bargaining power vis a vis unwanted conditionality.

Thus, both long term trends and cyclical variations in international capital markets, and in domestic financial systems, have been important determinants of the degree of influence of MDI's on Latin American countries. Such trends and cyclical variations have also determined both MDI's and recipient countries attitudes with respect to conditionality.

Figure 1. Gross flows from MDI's to LAC 7 as \% of total capital inflows and GDP (1980-2015)
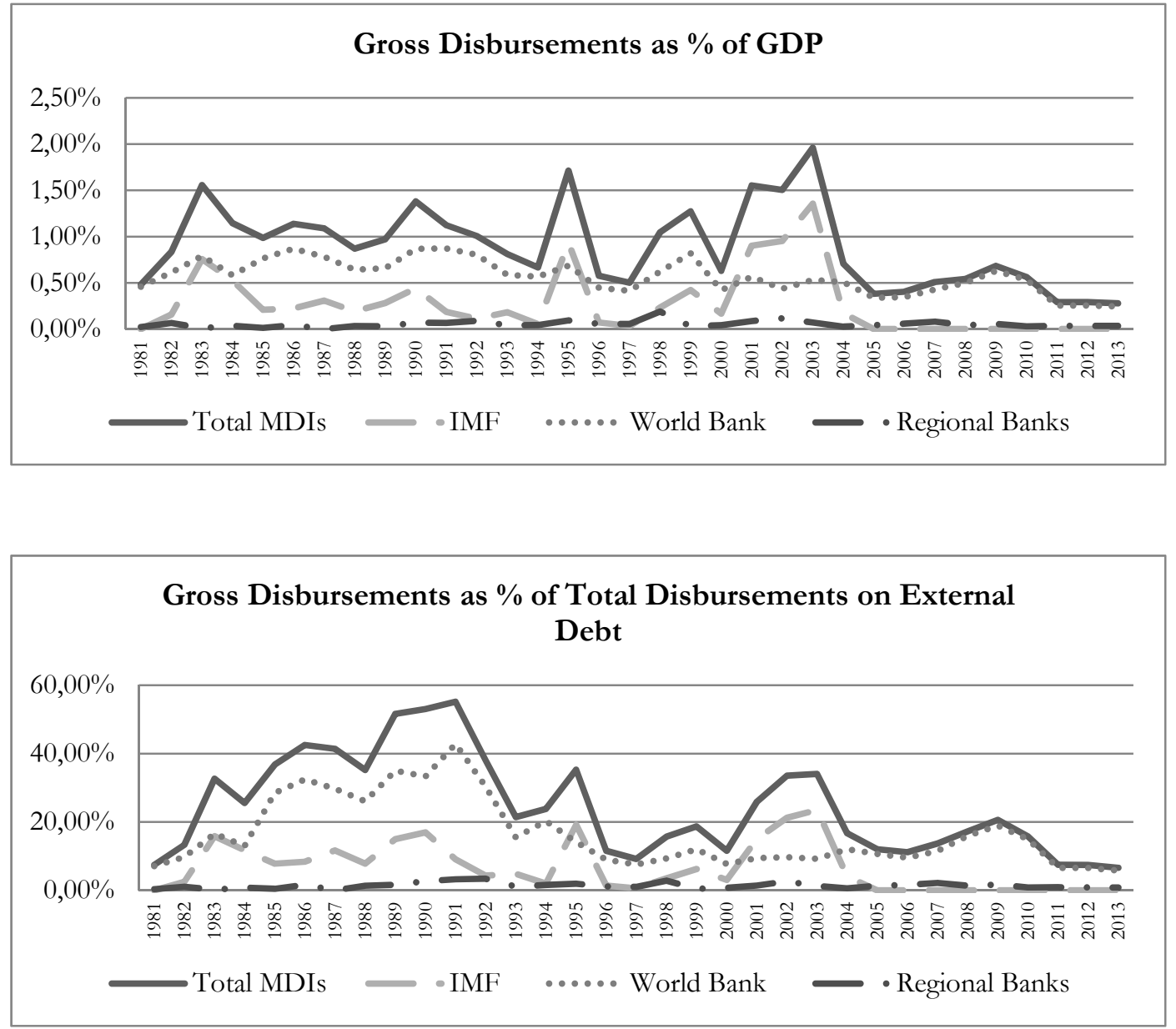

Source: World Development Indicators, CAF, IDB, IMF Debt Database. 
Figure 1 shows the sharp increase in the weight of IMF and MDB gross disbursements for the seven largest Latin American economies during the eighties, as a consequence of the interruption and reversal of capital inflows that took place after the US Federal Reserve interest hike of $1982^{7}$. This episode led to a series of public debt defaults and many countries in the region remained without access, or with precarious access, to international financial markets during most of the decade. Regional growth rates were very low during this so-called 'lost decade'.

Fiscal adjustment and restructuring of public debt through the Brady bonds ${ }^{8}$ during the second half of the eighties, coupled with the rapid growth of international capital markets in the nineties (Figure 2), gave rise to a vibrant market for international placements of Latin American bonds. Consequently, MDI flows participation in total gross capital inflows to Latin America decreased sharply, from a peak of 55\% during 1990-1991 to less than 10\% during 2011-2013, with temporary increases during regional or global crisis episodes, such as in 1995, $1999 / 2003$ and 2009.

Figure 2. Capital flows (global and to LAC 7): 1970-2015.

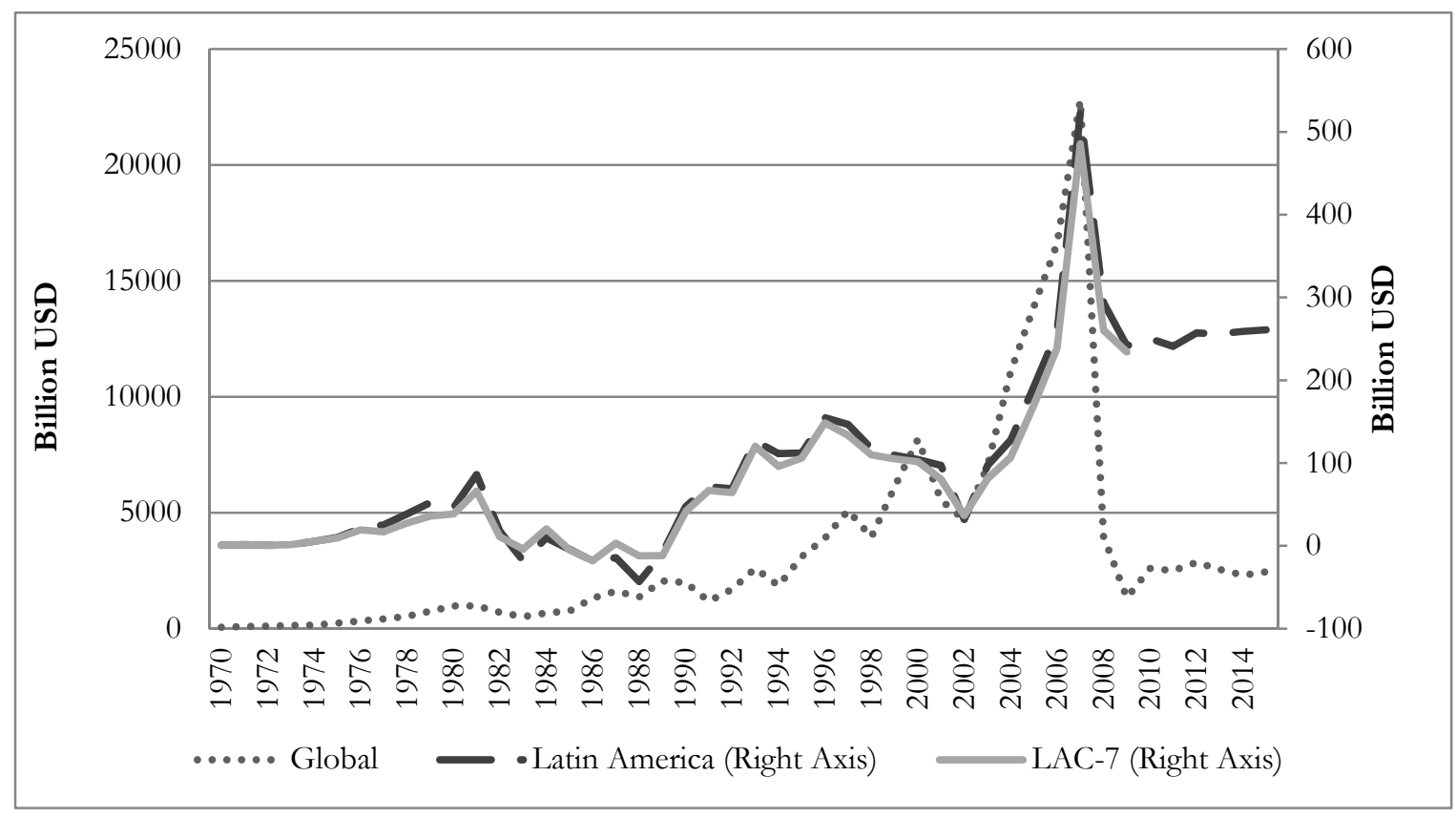

\footnotetext{
${ }^{7}$ Vegh, Calvo \& Reinhart (1994).

${ }^{8}$ Remaining Latin American debt to international banks was exchanged by long term sovereign bonds backed by US Treasury bills (and carried hence the name of the US treasurer, Nicholas Brady) at the end of the eighties. This automatically created a secondary market for Latin sovereign bonds and facilitated new primary issues. See Calvo (2008).
} 
Figure 3: LAC GDP and Capital Flows Annual Growth (1970-2015)

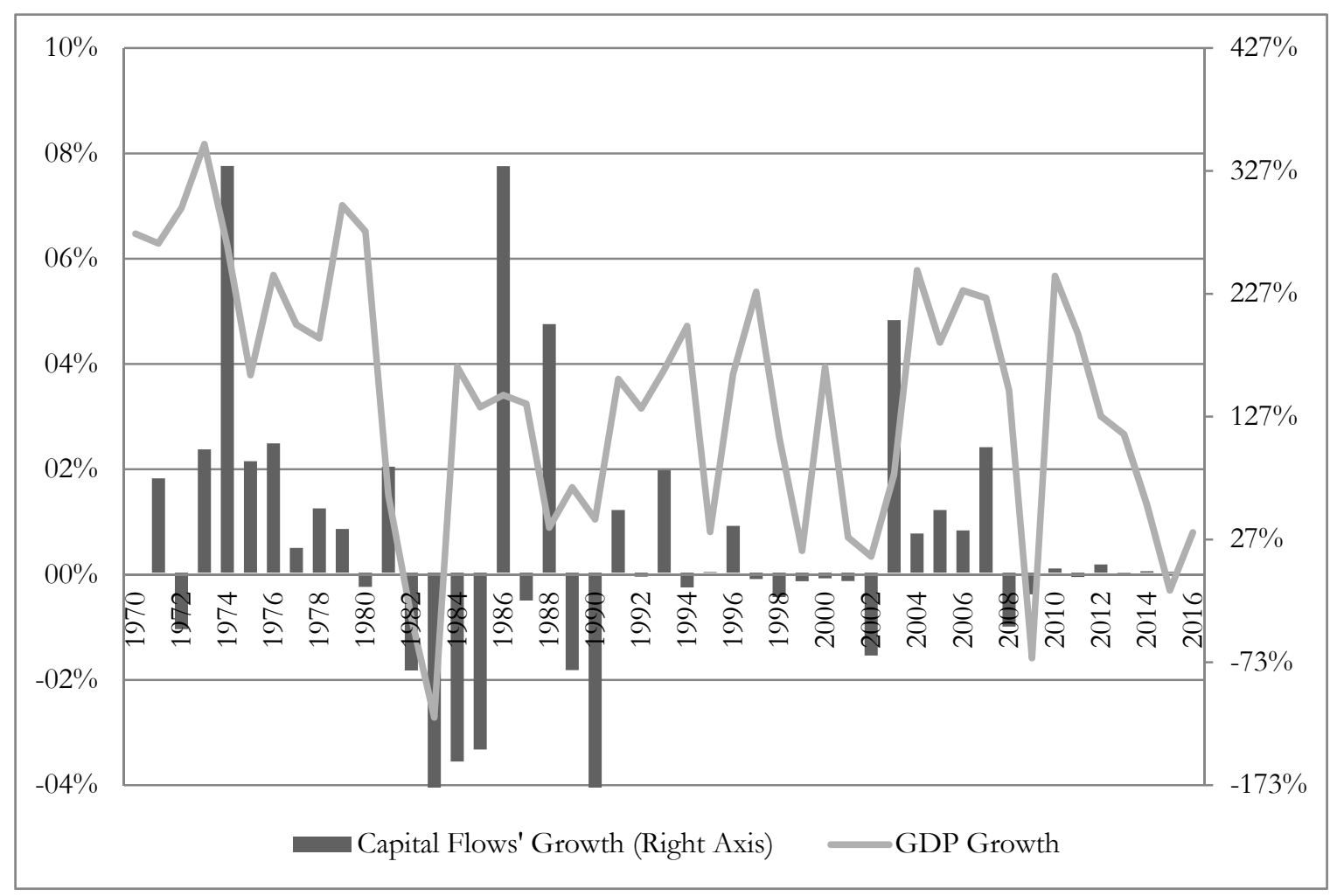

Source: World Development Indicators, CAF, IDB, IMF Debt Database.

In particular, the number of active programs of the IMF in the region peaked during the eighties at 22, and diminished ever since the early nineties to around 8 in 2013-2014 (Figure 4). FMI disbursements were dominated by the large programs to Mexico in 1995, after the 'Tequila' debt crisis of 1994, and to Brazil and Argentina from 1998 to 2003, when these two countries faced currency crises and sharp capital flows reversals after the 1998 Russian crisis. Similarly, MDB gross disbursements to the seven largest LAC economies (LAC 7), as percentage of total capital inflows, peaked in 1992 (at 45\%) and then dropped sharply to around $12 \%$ since 1996, with a rebound to $20 \%$ during the 2009 crisis (from $0.8 \%$ to about $0.3 \%$ of GDP), also with a temporary rebound during the global crisis of 2009 (Figure 1). They had local peaks around periods of crisis in the largest countries (México and Argentina 1995, Brazil and Argentina 1998-2001) and the global crisis of 2009 (Brazil, Mexico, Argentina, Colombia). (Figure 5) 
Figure 4A: IMF Disbursements and number of countries with active programs

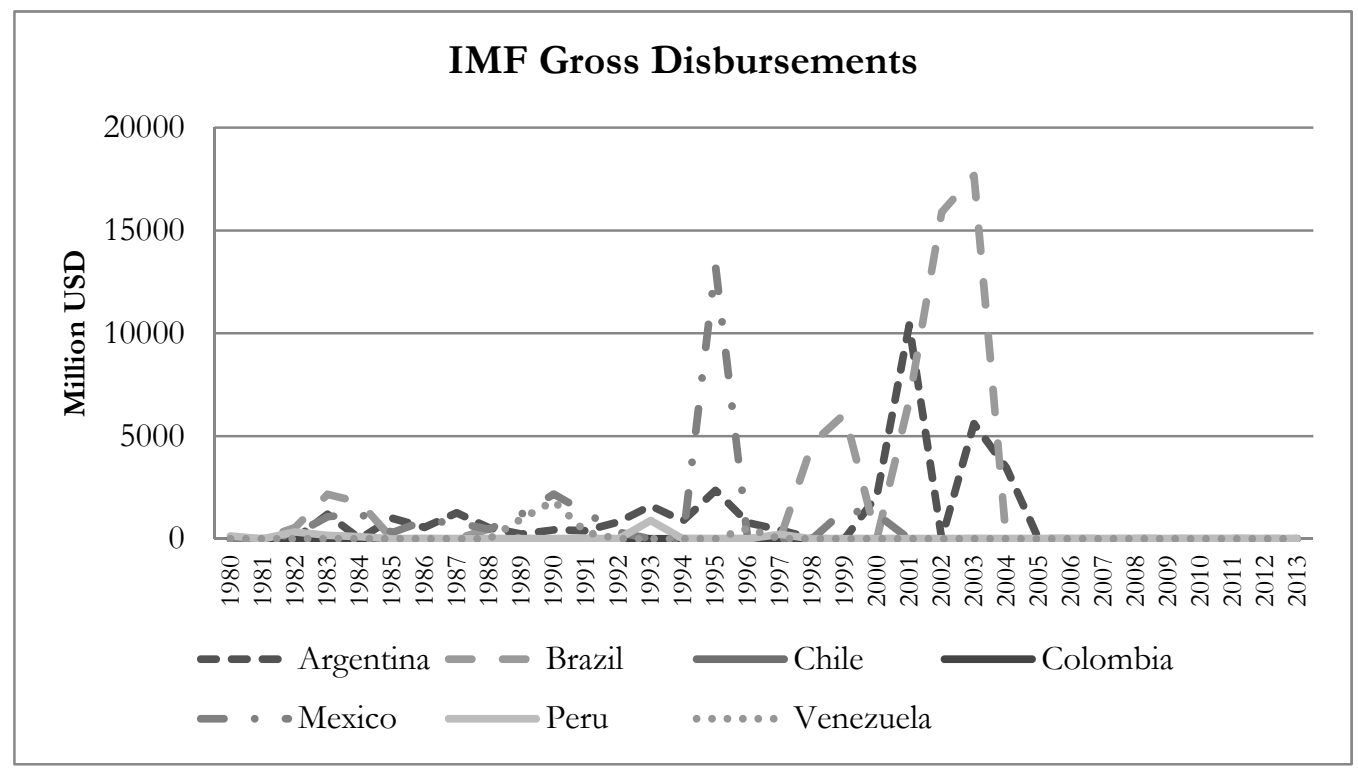

Source: World Development Indicators, CAF, IDB, IMF Debt Database.

IMF gross flows have been clearly counter cyclical, with respect to either private capital inflows or GDP growth (Table 1 in the Web version of this paper). This is consistent with its objective of support to countries experiencing balance of payments crises. MDB's flows, on the contrary, do not show a consistent pattern in this regard. They should also behave counter cyclically, ${ }^{9}$ or at least a-cyclically, given MDB’s long term development objectives. But they have often been pro cyclical because they often behave more as private banks than as development institutions. ${ }^{10}$ Nevertheless, a preliminary econometric exercise (see Table 7 in the web version of this paper) suggests that both MDB's and IMF's disbursements fulfill their objective of recovering and stimulating economic growth, albeit not immediately, with a three year lag.

\footnotetext{
${ }^{9}$ See Perry (2011).

${ }^{10}$ See, for example, Perry (2009).
} 
Figure 4B: IMF Disbursements and number of countries with active programs

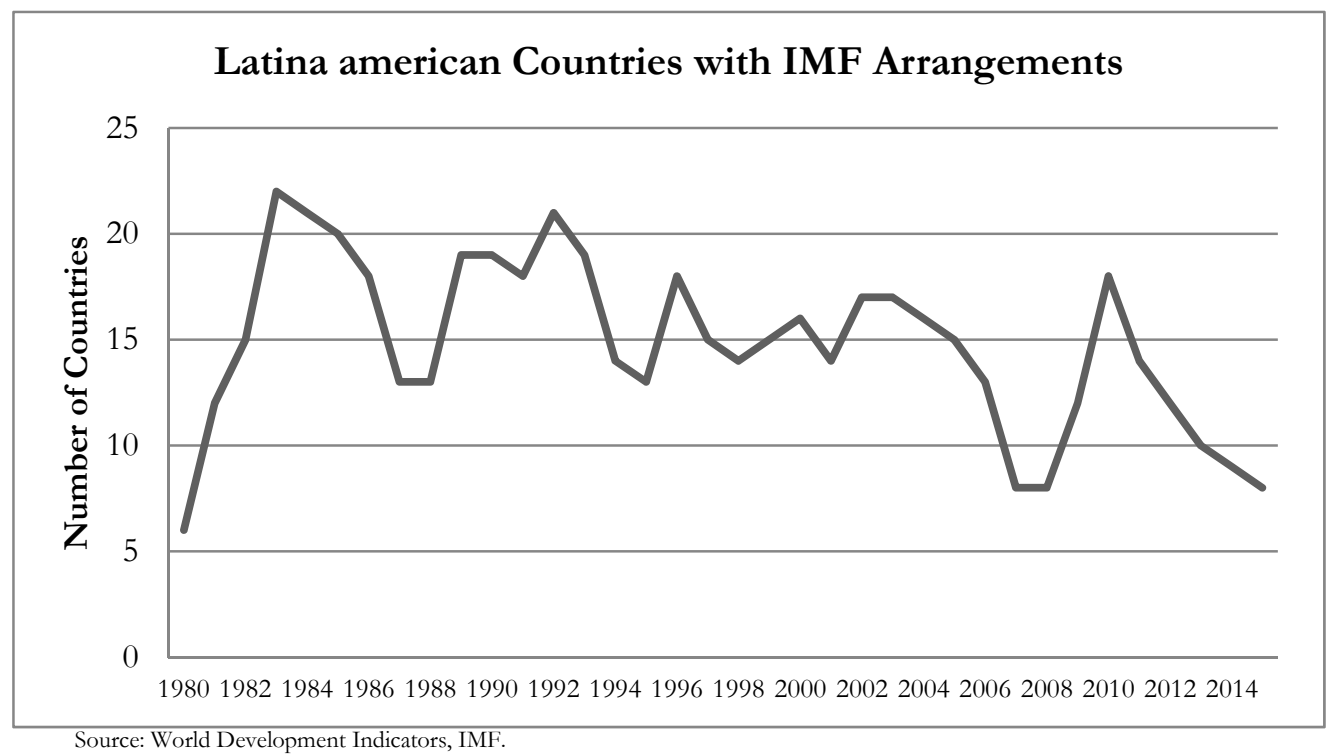

In parallel to these developments, several Latin American countries have been developing deep long-term markets for domestic currency government and corporate bonds. This has reduced the dependence of government finance from external sources, including MDB's (Figure 6).

It is thus not surprising that the height of MDI influence and conditionality was during the Latin American debt crisis of the early eighties, when most countries in the region requested IMF rescue packages and accepted the highly criticized 'structural adjustment loans' of the World Bank (this period is discussed further in Sections 3 and 4). In contrast, it was at an all-time low during the 2003-2008 and 2010-2014 periods, in which most Latin American countries were blessed with high and increasing terms of trade (due to high and increasing real commodity prices) -especially in South America- and an explosion of private capital inflows, both as a consequence of high international liquidity and good regional growth prospects. Thus, very few countries in the region needed access to IMF funds in this period and many of them reduced sharply their borrowing from MDB's. 
Figure 5: Total MDB Disbursements by Country

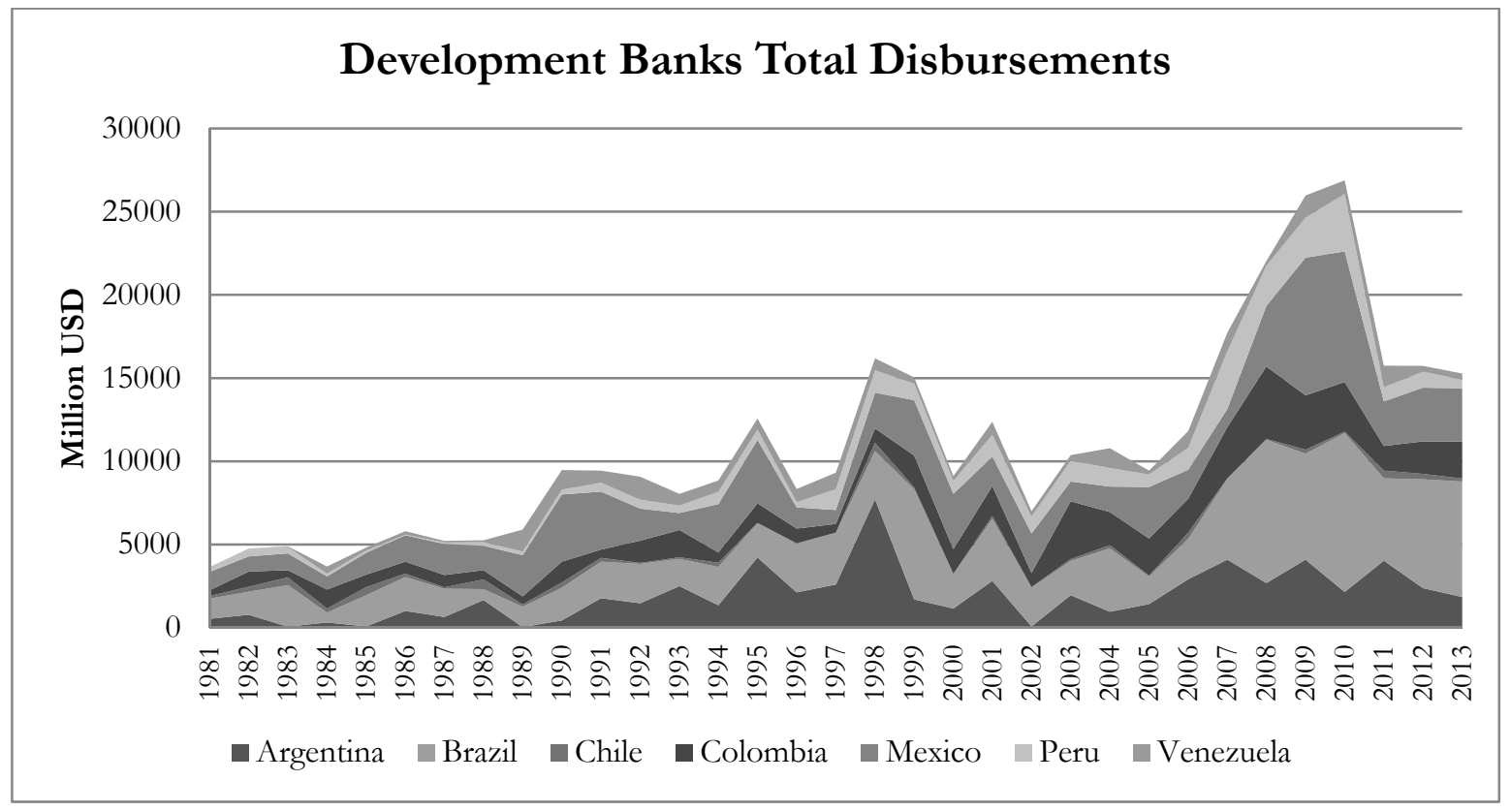

Source: World Development Indicators, CAF, IDB, IMF Debt Database.

Also not surprisingly, since the late nineties, but specially in the early 2000s, the IMF went into a period of 'soul-searching', trying to redefine its role and redesigning its financial instruments (flexibilizing access to its credit lines, e.g. the FCIL), in order to maintain relevance in fast growing developing countries. During this period, the MDB's and, to a lower extent, the IMF, began to talk about 'partnerships' and 'country ownership' of their own development strategies and adjustment programs. Consequently, the term 'conditionality' faded away significantly from official documents.

Further, worried about their business prospects, MDB's were busily designing 'MIC strategies', intended to lure middle income countries that had achieved easier access to cheaper and longer term private financial resources, into maintaining some lending and technical assistance relations with MDB's. ${ }^{11}$ For the same reason, most MDB's ever since have been actively increasing their lending to the private sector and to public enterprises or subnational governments without sovereign guarantees. ${ }^{12}$

\footnotetext{
11 Perry (2011)

12 Perry (2009)
} 
Figure 6: External Public and Publicly Guaranteed Debt Stocks (\%GDP)

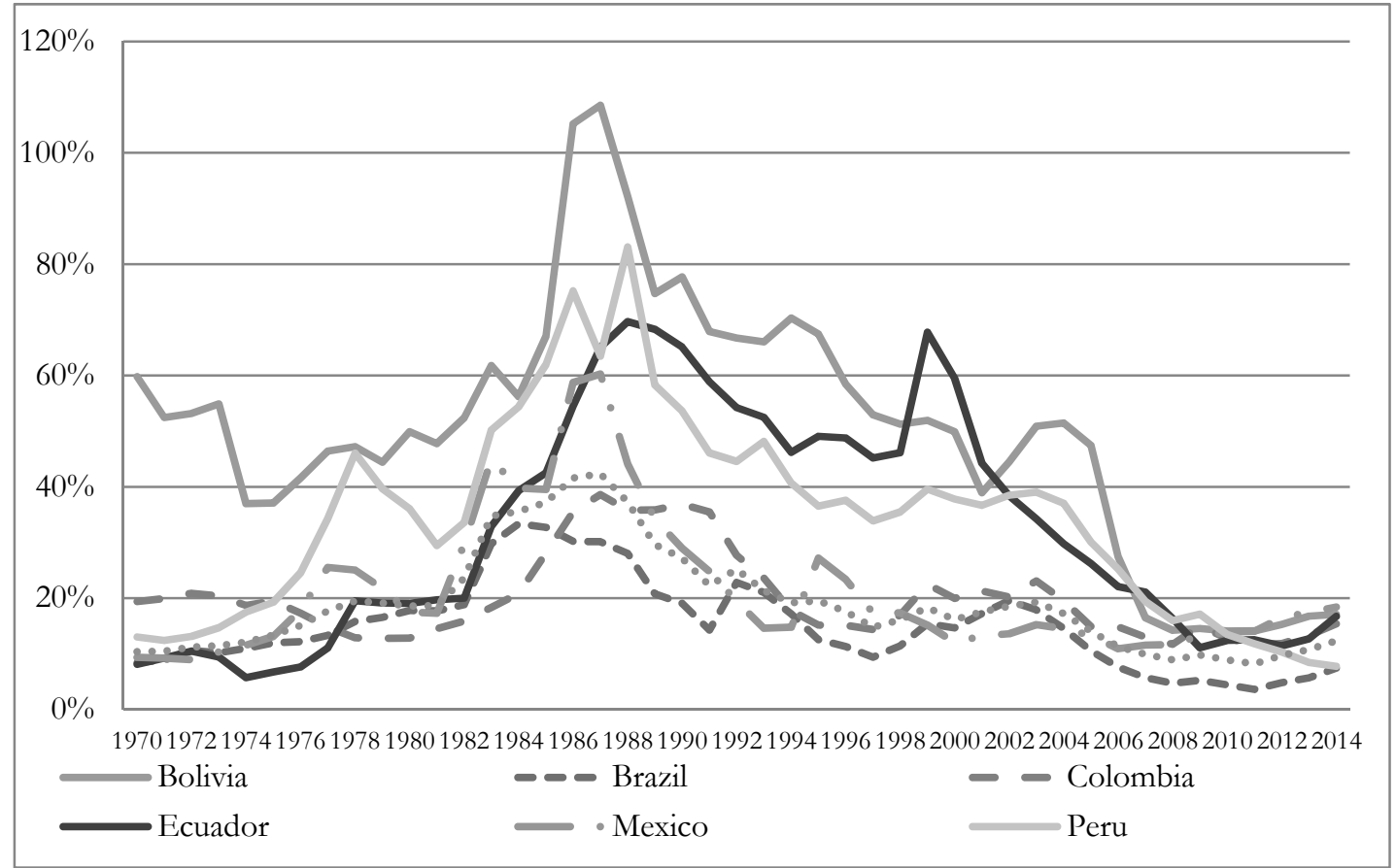

Source: World Development Indicators, IMF. External Debt is defined as all debt owed to non-residents in foreign currency.

Figure 7: MDI Lending to Private Sector (Global)

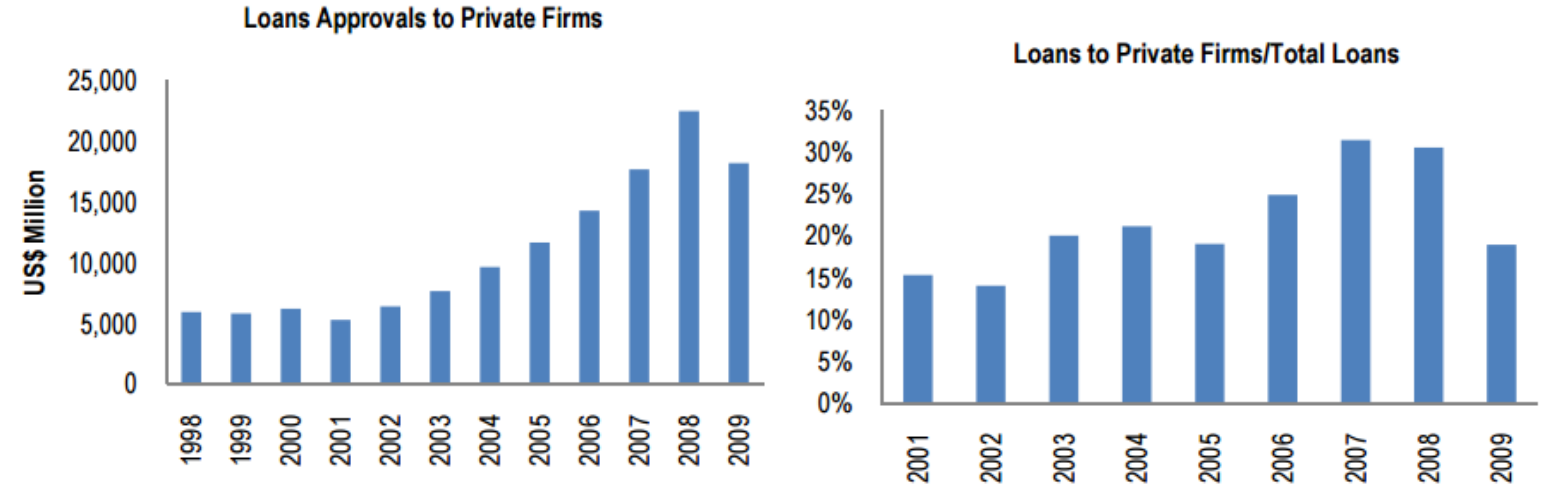

Source: “Growing Business or Development Priority”, Perry G., 2011, Center for Global Development.

The 2009 global crisis, with its sharp reduction in private capital flows, constituted a temporary reversal of these trends and was a stark reminder to MIC countries that they may still, on occasions, need to access IMF and MDB's resources, and thus should keep reasonable working relations with them. Something similar, though less markedly, has happened after the sharp reduction in commodity prices since 2013. So far, most Latin American countries have 
avoided major currency, fiscal and financial crises and it seems unlikely that they will do so, as macro-financial vulnerabilities have been significantly reduced in comparison to the past ${ }^{13}$.

As a consequence, it is unlikely, at present, that the relative importance of MDI lending and influence return any where near to the level of the eighties. This said, if present difficulties in Brazil worsen considerably, total MDI flows to the region might hike up significantly, given the weight of the Brazilean economy in the regions GDP and total capital inflows, its potential spillovers over neighboring countries and eventual financial contagion over the rest of the region.

Size matters -A complement to this story is that MDI's influence has always been larger in countries with more underdeveloped domestic financial markets and scant access to international financial markets, especially if, at the same time, they are small countries with little political clout. It is well known within the international community that large countries such as China, or, in Latin America, Brazil and Mexico, and previously Argentina, usually receive VIP treatment (conditionality is lower and country views are hold with more respect) than small countries such as Bolivia, Ecuador or Nicaragua. Middle sized countries with good access to private markets, such as Chile and Colombia, have also been darlings of MDI's. To be fair, it is also true that countries such as Brazil, Chile, Colombia and Mexico (and Argentina in the nineties) have had stronger technical teams, more able to design good programs and persuade MDB technocracies about their own views, than some other countries in the region.

In summary, the degree of MDI Influence has been a function of both the relative value of MDI resources for individual countries at any point in time (being larger in periods of private capital flows retrenchement and macroeconomic crisis) and the relative lack of technical capacities and political clout of beneficiary countries.

\footnotetext{
13 Perry, CGD (2014). There are, of course, exceptions that may eventually require major IMF and MDB financing.
} 


\section{MDI orthodoxy and 'paradigms': a moving target with Latin American inputs}

\subsection{Changing views at the Multilateral Development Banks}

Easterly ${ }^{14}$ showed eloquently how World Bank views on development significantly evolved over time. Initially, in the fifties and sixties, the WB considered building adequate public infrastructure as the key to development and, consequently, had a lending portfolio highly concentrated in Infrastructure Investment Projects ${ }^{15}$. Increasingly, building human capital was seen as a complementary development handle, thus broadening the Investment Portfolio to the social sectors, and poverty reduction became a complementary objective to growth.

By the early eighties, the Bank came to the view that what mattered most for development (and for 'aid effectiveness') were pro-market policies (considering as such trade opening, prudent macro-financial policies and promotion of private investment), thus broadening again the portfolio with wholesale policy-based lending through Structural and Sectoral Adjustment Programs. This was the period (the eighties and early nineties) associated with the so-called Washington Consensus. It coincided with the height of MDI influence in Latin America due to the regions external and financial crisis, as discussed in the previous section.

MDB views during the fifties and sixties were heavily influenced, among others ${ }^{16}$, by Albert Hirschman views based on his Latin American experience (Lessons from Development Projects). On the other hand, the contents of the Washington Consensus, and its very name, were drawn by John Williamson from the proceedings of a Washington-based conference attended by several high level Latin American policy makers ${ }^{17}$. Indeed, a new generation of highly influential Latin American technocrats and politicians, disappointed with the slowing productivity performance of the region, and the debt crisis, had become convinced of the need

14 Easterly (2001)

15 A view influenced by growth and development theories in vogue in the fifties and sixties (Harrod-Domar, Rosenstein Rodin, Hirschman) and by the initial experience of the World Bank in the reconstruction of Europe after the War, which was mostly a huge infrastructure (restoration) investment program.

${ }^{16}$ See Hirschman (1995). Most of the so-called 'development economics', from Harrod-Domar growth models to Rosenstein Rodin's 'big push', saw increases in investment rates as the cornerstone to increase growth rates, and in particular in public infrastructure, which was seen as crucial to integrate internal markets and permit the development of modern industry.

17 Williamson (2004). 
of opening up the economies, reducing the scope and intensity of Government intervention and adopting prudent macro-financial policies. Thus, they were autonomously pushing for them.

As a consequence, the conventional view that the reforms that took place in many Latin American countries during the eighties and early nineties were just impositions from the IMF and the WB is exaggerated in some cases (as there was rather the concurrence of badly needed resources and shared views) and in others clearly flawed. Thus, for example, there was very little IMF or WB influence in the pioneering Chilean reforms of the mid-seventies (associated rather with the local 'Chicago boys' empowered by the authoritarian regime of Pinochet) or in their deepening and development during the center-left 'Concertacion' governments of the nineties. Quite on the contrary, Chile often adopted reforms that only latter on were promoted by the MDI's in other countries and latitudes, such as the pension reforms of the eighties (based on individual savings and capitalization funds, mostly privately administered) or the fiscal rule ${ }^{18}$ of the late nineties (see below).

And though there was intellectual influence, there was more a meeting of minds than MDI imposition in the reforms enacted by the governments of Salinas in Mexico, Menem in Argentina (the 'convertibility' regime was not only home grown, but not enthusiastically seen in some of the MDI's -see below-), Fujimori in Peru, Gaviria in Colombia and Cardoso in Brazil (kept and deepened by the Lula government), among others which took place in the late eighties and early nineties.

Colombia, for example, had easy access to private international capital markets and did not have an IMF program at the time when Washington Consensus type reforms were enacted. Moreover, in the previous 25 years had only had a monitoring IMF program (without IMF financial resources) in $1983^{19}$ and only required access to IMF funds during its 1999 crisis, almost a decade after enacting the Washington-Consensus type reforms ${ }^{20}$.

\footnotetext{
18 The Chilean fiscal rule requires to keep a 'structural' balance in surplus, thus making it compulsory to save in periods of high copper prices and fast economic growth. The rule has led to a significant stability of real government expenditures along economic cycles, removing the pro-cyclical patterns of expenditures characteristic of Chile's past history and most of Latin American countries even today. See below. ${ }^{19}$ Junguito (2015).

${ }^{20}$ Edwards and Steiner (2008), Junguito (2015) op. cit.
} 
Later on, since the mid-nineties, the WB (and IDB) evolved towards a more holistic view of development, in which other factors acquired a role at least as important as the core Washington Consensus tenets. In particular, a series of World Bank analytical reports began to emphasize, since the mid-nineties, the critical importance of institutions for growth and development ${ }^{21}$. This led to a new portfolio of loans related to institutional reform in a wide variety of fields and the development of a set of measures of institutional quality (the Kaufman-Kray Governance indexes) ${ }^{22}$, which have become benchmarks of reference.

The re-emergence of this key concern, virtually absent during the Washington Consensus period, was due both to the growing influence of the 'new institutional economics' of North, Coase and others ${ }^{23}$, and the stark evidence of initial failure of market-oriented reforms (supported by the MDI's after the fall of the Berlin wall) in Russia and other Soviet Union states and areas of influence, where there was a significant lack of market-supportive institutions ${ }^{24}$.

Similarly, MDI's initial enthusiasm with some big-bang reformers in Latin America, became more subdued when it began to be realized that such reforms might as easily be done or undone in countries characterized by weak institutions, such as Argentina ${ }^{25}$, while they demonstrated greater resilience and delivered better fruits over time in slow reformers, such as Costa Rica and Uruguay, where the both the slow pace and the resilience of reforms were intimately connected to their more mature democratic and political institutions.

Correspondingly, there was a significant revaluing of the role of the State at the MDB's. Thus, at the World Bank, the intellectual debate about too large vs small states, that characterized the era of the Washington Consensus, shifted towards the discussion about strong and competent vs fragile and failed States. ${ }^{26}$ Public investment in infrastructure, that had fallen into a benign neglect during the Washington Consensus years, alongside a naive faith on private participation, was revalued. A more balanced view about its importance and

\footnotetext{
21 Burki \& Perry (1998)

22 Kaufman, Kray \& Mastruzzi (2010).

23 See North (2010) and Coase (1960). Institutionalist views on development had been popular among many schools (such as the Austrian school), before the dominance of neo-classical economics.

${ }^{24}$ See Stiglitz (2002).

25 Argentina was the poster child of Washington Consensus type-reforms and president Menem was invited to be a key-note inaugural speaker at the IMF/World Bank Annual Meetings in 1996.Such reforms were significantly overturned after the 2001 crisis.

26 See World Bank (1995).
} 
the complexity of public-private partnerships, emerged with pressure from the academic community and Latin American governments. The competition of CAF played a major role in this latter revival of interest, as dicussed below.

Similarly, during the Wolfhenson mandate, poverty reduction became the main explicit objective of World Bank support ${ }^{27}$ and the share of anti-poverty programs increased sharply within the Bank's portfolio. The World Bank has been since associated with most conditional cash transfer programs (as was the case in Brasil, Colombia and Peru), though it had had nothing to do with the enactment of the pioneer and most famous of these programs ('Progresa', afterwards renamed as 'Oportunidades', in Mexico). ${ }^{28}$

Also, since the nineties, the World Bank Group has been a pioneer on Environmental and Social Sustainability and Climate Change concerns. The so-called environmental and social 'safeguards' (which IDB and CAF have also implemented) have affected the approval, design and operation of public and private projects in infrastructure and other areas, contributing to heightened standards in the region. In addition, there has been a substantial body of research in these areas at the Bank and an important portfolio, financed by the Global Environmental Fund.

An additional example relates to innovation and industrial policies. From the fifties to the seventies, the World Bank supported many public industrial projects, as well as private manufacturing through lines of credit to Central Banks and local development banks. Such operations were, however, suspended in the eighties and nineties as part of the new views, under the Washington Consensus era, that favored free trade and the reduction of government intervention in industry. However, critiques from academia ${ }^{29}$, and the rising evidence and belief in Latin America and other regions that trade opening is, by itself, not enough to promote export-led growth, as suggested by early proponents, led to an intellectual revival of 'industrial policies' (more precisely, sectoral policies), oriented towards providing specific sectoral public goods and overcoming coordination failures. These views are beginning to make inroads

\footnotetext{
27 'A World without poverty' became the Banks official vision in its mission statement. Poverty reduction programs had existed since Mc Namara's times, but had not achieved prominence in WB operations.

${ }^{28}$ As importantly, the concept of equality of opportunity, as a basis for higher and more equitable growth, was introduced in a series of reports, most notably in the Equity and Development WDR of 2006. However, it is not clear to what extent this concept has permeated actual Bank operation.

${ }^{29}$ Rodrik, Haussman et al (2002).
} 
within the development banks, though they are not yet an important part of their 'official ' doctrine or lending portfolio.

Simultaneously, there has been some reconsideration of the role of national development banks which, ironically, were seen as superfluous or inconvenient by the multilateral development banks during the Washington Consensus era. Successful initiatives of Corfo in Chile, Nafin in Mexico, Bndes in Brazil, Bancoldex in Colombia and Cofides in Perú, have had significant influence in this revision of MDB's doctrine, and IFC and CAF have even become minority shareholders in Cofides, and in the newly created FDN in Colombia.

As a final example, there is an emerging discussion within the MDB's about integrating human rights views into development strategies. Specifically, the discussion is around the need or convenience of approaching basic service delivery (education, health) from the perspective of citizens' rights, and not just from the perspective of traditional 'social policy'. This initiative is still at its infancy within the MDB community, but it is probable that, as in other aspects just mentioned, it may eventually become part of the official doctrine.

\subsection{Changing views at the IMF}

IMF 'orthodoxy' has also had an important evolution over time, on diverse topics central to this agency's core business. These changes have usually been influenced by academic research, but also by policy debates with the MDB's and with Latin American (and other developing countries) authorities, as discussed below.

The IMF was created to support the Breton Woods system of fixed exchange rates and capital controls, through financial support during periods of balance of payments crisis. However, Latin American and other developing countries attempts to maintain fixed parities resulted in frequent currency crises, followed by massive devaluations towards a new fixed parity, and, as a consequence, in very high output and inflation volatility. The effects of adverse external (or domestic) shocks were exacerbated by pro cyclical monetary policies that attempted to defend fixed parities and contain erosion of reserves, until they had to enact or permit massive devaluations, when it became obvious that the former parity could not be maintained. IMF advice and programs were important factors behind these 'stop-and-go' cycles of policies which exacerbated business cycles. There were major confrontations between 
the IMF and some countries about these policies, the most notable when Colombia adopted a crawling exchange rate system and generalized capital controls in $1966 .^{30}$

After the demise of the Bretton Woods system, IMF advice evolved towards increasingly supporting exchange rate flexibility. In particular, during the following decades, the IMF supported the managed crawling pegs instituted by Colombia, Brazil and Chile. However, due to rising concerns about the fact that such regimes contributed to price and wage indexation and persistent moderate inflation, IMF advice, and these countries policies, eventually shifted (at the end of the eighties or beginning of the nineties) towards 'crawling exchange rate bands', within which the currency was allowed to float. Later on, as high volatility of capital inflows made it difficult, or very costly, to defend such bands, IMF advice, and these countries' policies, turned to favor full exchange rate flexibility. There was a parallel evolution on views about monetary regimes, progressively leaning towards support of inflation targeting regimes, which are consistent with exchange rate flexibility, and permit the deployment of counter cyclical monetary policies. ${ }^{31}$

However, it should be noted that even until recently, IMF programs supported on several occasions unsustainable overvalued fixed-exchange rate systems (such as the Argentinean currency board from 1997 until 2001), or bands (as in Brazil in 1998/99), in spite of internal misgivings. Evaluations from the IEO have been especially critical of the fact that the IMF failed in pointing out the high degree of vulnerability of the Argentinean currency board, in not promoting an early ordered exit, and in continuing to support the regime in 2000-2001 when it was clearly unsustainable. These cases highlight the fact noted in Section 2 that large countries with high political clout are often treated in a more deferent way, even when in the IMF staff had serious misgivings about their policies. ${ }^{32}$

This evolution of IMF advice with respect to exchange rate management proceeded in tandem with its views about capital account opening. Article 4 consultations criticized the capital controls instituted by Brazil, Chile and Colombia and other countries, though, on occasions, the IMF Board recognized that their use could be a legitimate tool, when they acted as complements to sound macro-financial policies in order to avoid destabilizing surges of

\footnotetext{
${ }^{30}$ Espinosa (1970); Junguito, R (2015).

${ }^{31}$ For lack of space we do not refer here to the abundant literature on this topic. See, for example, Ebeke \& Fouejieu (2015) and Batini, Breuer, Kochhar \& Roger (2006).

32 See Independent Evaluation Office (2004) and Perry and Serven (2003).
} 
short term capital inflows. ${ }^{33}$ In 1997 IMF management proposed changing the IMF statutory chart to require full capital account opening of its members. This initiative was strongly opposed by an active coalition of some Latin American and Asian countries ${ }^{34}$ and, as a consequence, failed to be approved in the IMF Assembly of that year in Singapore. Shortly after the Asian crisis erupted, demonstrating, once more, ${ }^{35}$ the dangers of fast and inadequate capital account opening. As a consequence, the IMF position on capital controls evolved into a more nuanced position. Recently, the Fund has explicitly recognized the advantages of dirty floating and Central Bank foreign exchange interventions in dollarized economies (such as $\left.\operatorname{Peru}^{36}\right)$, as a means to avoid excessive appreciations and depreciations that may lead to balance sheet problems and financial instability.

As this account suggests, some Latin American innovations and positions had an influential role in this evolution of IMF policies on exchange rate management and the occasional use of capital controls.

Similar changes have taken place in IMF positions on fiscal issues. The IMF recommendations and programs were often criticized from many quarters for placing excessive emphasis in short terms goals, without due consideration to business cycle or long term effects. In particular, the focus on short term fiscal goals in Fund programs and advice often led in Latin America to inconvenient pro cyclical fiscal policies, excessive cuts in public infrastructure and lack of concern with term and currency composition of public debt. ${ }^{37} \mathrm{~A}$ significant body of research demonstrated the highly pro cyclical character of fiscal policies in Latin America ${ }^{38}$, drawing attention to political economy and financial sector determinants of these phenomena, but also to the role played by IMF short term fiscal goals that did not adjust for cyclical factors.

Chile was the first country in the region to break out of this vicious circle by enacting in 2001 a fiscal rule responsive to the domestic business cycle, as well as to deviations of the price

\footnotetext{
33 See, for example, the Board Statement about the completion of Article 4 consultations in Colombia in 1995.

34 The main author of this paper was personally involved in this dispute.

35 See for example Lora (2000) or Forteza, Tommasi and Herrera (2006).

36 See, for example, IMF (2015).

${ }^{37}$ See a thorough discussion of these issues in Perry, Serven and Suescun (2004).

38 Haussman et al (1996), Vegh \& Talvi (2005) . The IMF has recently acknowledged those contributions. See Klemm (2014) and Bova, Carcenac and Guerguil (2014).
} 
of copper (its main source of foreign exchange and fiscal revenues) from its long run trend. ${ }^{39}$ Colombia in 2011 and Peru in 2015 also enacted rules similar to the Chilean. All three of these fiscal rules are at least cycle-neutral and they allow for some degree of counter cyclicality in special circumstances.

The IMF gradually became a supporter of these policy innovations. Even more, since the 2009 global crisis, it became a strong advocate of counter cyclical fiscal policies in industrialized and developing countries with enough fiscal space, and of more gradual pro cyclical fiscal adjustments when such adjustments are unavoidable for long term sustainability $^{40}$. Still, a 2013 evaluation from IEO ${ }^{41}$ concludes that, although the IMF has made progress in this area, since the previous highly critical assessment undertook in $2003^{42}$, it continues to fail to take sufficiently into account the critical need of counter-cyclical fiscal policies in commodity-dependent countries, such as most of South American nations.

Similarly, pioneering studies from the World Bank on the 'public infrastructure lags' in many Latin American countries, showed that they often originated in the sharp fiscal adjustments of the eighties and early nineties, under IMF programs, after most countries in the region had to default on their public debt. ${ }^{43}$ Analysts in the MDB's drew attention to the high long term growth costs of such adjustments ${ }^{44}$ and to their inefficiency and eventual failure from an intertemporal perspective ${ }^{45}$. Recent advice of the IMF to European countries, recommending the implementation of a major infrastructure investment program, as a means to stimulate aggregate demand in the short run and to increase productivity in the long run, suggest a significant reconsideration of these issues.

More generally, IMF advice and programs have been increasingly sensitive to the quality of fiscal adjustments, trying to limit their effect on anti-poverty programs and badly needed

\footnotetext{
${ }^{39}$ See Perry (2003), Frankel (2010) and Valdés et al (2011) among others.

40 Blanchard \& Leigh (2013).

${ }^{41}$ See Independent Evaluation Office (2013).

42 See Independent Evaluation Office (2003). This evaluation indicated that most program fiscal adjustments were excessive (led to excessive current account corrections and recessions) because they over-estimated growth recovery and had fixed goals that were not sensitive to cyclical events.

${ }^{43}$ Calderon and Serven (2010).

${ }^{44}$ Calderon and Serven (2010), op. cit.

45 See Easterly (2003).
} 
infrastructure investment. ${ }^{46}$ Consequently, the IMF has began to accept that infrastructure concessions investment costs may be spread out during the economic life of projects, if construction risks are born by private firms, and thus would not show up as sharp increases of fiscal deficits and public debt in the short run. ${ }^{47}$

In a similar vein, the World Bank and the IDB began to call attention in the late nineties to the fact that several recent fiscal crisis, in Latin America and elsewhere, had not originated in excessive fiscal deficits and public debt levels (at least as commonly measured at prevailing exchange rate levels), but in currency mismatches that led to unsustainable debt levels when adverse shocks required sharp currency devaluations. ${ }^{48}$ The IMF has gradually incorporated these issues in its surveillance work and programs.

Equally important, responding to WB and Latin American critiques about the adverse effects of adjustment programs on poverty levels, IMF programs began to protect anti-poverty programs from overall required fiscal expenditure cuts, since the mid-nineties. Further, in 1996 the Fund joined the MDB's in launching the Heavily Indebted Poor Countries program (HIPC), which since then has engineered 36 debt alleviation programs in such countries, designed to reduce the burden of debt and required fiscal adjustment on growth and poverty levels. It also launched in 1999, the Poverty Reduction Strategy Papers (PRSP), as a joint effort with the World Bank and low-income countries authorities to guarantee not only that required macroeconomic adjustments programs had the minimum potential effect on low income groups, but that coordinated MDI support would help faster poverty reduction over the medium term. These programs were prompted by debates about the effects of IMF programs in the poorest countries of Africa and Asia ${ }^{49}$. In Latin America, a region dominated by Middle Income countries concerns, they have benefited countries such as Haiti, Bolivia and Nicaragua.

\subsection{Diversity and competition among the MDI world}

The previous account illustrated significant differences between MDB technical views and IMF official positions on several topics that affected Latin American and other developing

\footnotetext{
${ }^{46}$ See Independent Evaluation Office (2013), op.cit.

${ }^{47}$ This is, for example, the case with the ambitious $4 \mathrm{G}$ highway program currently under execution in Colombia

${ }^{48}$ IDB (2007); Fiess (2004); Perry, Suescun and Serven (2004).

49 Stiglitz, Making Globalization Work (2006).
} 
countries. Some of these debates originated around experiences in other regions, as was the case of IMF program effects on poverty, and notably during the 1997 Asian crisis. ${ }^{50}$ Although these debates were not centered on Latin American issues, there were several instances of such clashes about Latin American programs. In particular, strong criticism by the World Bank on the way that IMF programs dealt with financial crisis led eventually to a significant strengthening of IMF technical capacity in this area and the joint Financial Sector Assessment Programs (FSAPs) ${ }^{51}$.

In summary, often Latin American and other developing countries have not been faced with a unified 'orthodox' view from the Washington based institutions. Such diversity of views between the IMF and the World Bank and the IDB have on occasions led to the IMF changing or moderating initial policy positions that had negative effects on Latin American economies.

Diversity of views and competition among MDB's played other useful roles. As already mentioned, at the height of Washington Consensus ideological excesses, WB and IDB support for public infrastructure projects faded away, with the naive belief that with adequate regulation and concession contracts private investment in infrastructure could largely substitute for the need of public funds ${ }^{52}$ Although this became true in the areas of telecommunications and energy, it was never the case in transport or water supply and sewerage infrastructure. Fortunately, CAF, an MDB created, funded and managed exclusively by Latin American countries, did not buy into these extreme views and decided to fill the vacuum left by the World Bank and IDB. By 2010 it was lending more to public infrastructure projects in Latin America than those two institutions taken together. Later on, the Washington based MDB's recognized their mistake, and the business opportunities lost to CAF, and began to engage again more forcefully in this area.

\footnotetext{
50 See Stiglitz, op.cit.

51 IMF initial actions in the Indonesian crisis of 1998 (closing banks in the midst of the crisis) led to deeper financial crisis (IEO, op. cit.). There were also disagreements in the WB with respect to the Fund positions in dealing with the financial crisis in Jamaica and the DR (against the bailing out of off-shore debtors) and with the Argentinian financial crisis in 2000 (against the asymmetric pesification of dollar deposits and loans). All these criticisms led to the IMF decision to strengthen its capacity on financial issues and instituting the FSAP program with the WB.

${ }^{52}$ Environmental and social safeguards are also responsible for the underinvestment in infrastructure projects.
} 
This is only one case, albeit the most notable one, in which diversity of views and competition among MDB's have facilitated Latin American countries to 'shop around' and find required cheap long term financing, without having to accept unwanted MDB conditionality.

The existence of FLAR has played a similar role, though significantly more limited, for small countries in LAC in need of balance of payments support. However, more often than not, FLAR support has played the role of a complementary source to IMF resources, acting as a 'lender of first resort', while an IMF program is put together, taking advantage of the fact that it can proceed much faster than the IMF. ${ }^{53}$

The fact that IDB, and specially, CAF have often been more flexible than the WB in supporting home-grown regional government programs and policies probably has had something to do with the fact that a larger portion of their staff come from the region, and hence are more knowledgeable of specific country circumstances and sympathetic to them. In the last analysis, it reflects the stronger weight of Latin American countries in their boards. This is particularly true of CAF (and FLAR) which are fully owned and directed by Latin American governments and, as a consequence, have no influence of extra-regional Agendas. Further, they have built Governance structures that leave more flexibility to the administration in order to accommodate to specific and changing country circumstances. ${ }^{54}$

\section{Orthodoxy and heterodoxy reconsidered: from stereotypes to realities}

Though 'orthodox' views in the MDI world have changed over time, as illustrated in Section 3, the main tenants of their recommended macroeconomic policies, fiscal and monetary discipline and trade openess, have remained fairly constant since the eighties. Indeed, though changes in MDI's official doctrine overtime include new views on the desired degree of exchange rate flexibility and financial integration (capital account opening), counter cyclical fiscal policies and the quality of fiscal adjustments, the most significant changes in official doctrine of MDI's were related to the micro-economic determinants of growth (especially on the role of institutions) and on the increasing weight placed on equity and long term sustainability issues.

\footnotetext{
53 See several papers included in FLAR (2015).

54 See Perry (2016).
} 
During the last decades most left-wing Latin-American governments embraced those basic elements of 'orthodox' macro-economic policies: fiscal and monetary discipline and trade openness. ${ }^{55}$ The administrations headed by Lula in Brazil, Lagos and Bachelet in Chile, Tavaré Vasquez and Mujica in Uruguay, Ortega in Nicaragua, Evo Morales in Bolivia, Toledo and Humala in Perú, and to a lesser extent Correa in Ecuador, clearly followed disciplined fiscal and monetary policies, as strict or more than those of their antecessors, and similar to those of contemporary center-right governments in other Latin American countries, such as Pastrana, Uribe and Santos administrations in Colombia and Fox, Calderon and Peña Nieto in México.

Although fiscal deficits and inflation do not depend only on government policies, the figures shown in Tables 2 and 3 (found in the Web version of this paper) are quite suggestive. They show, for example, that the process of fiscal consolidation and reduction of inflation rates initiated by the Cardoso administrations was deepened under Lula, though the fiscal situation deteriorated slightly under the first Dilma Rousseauf term. They also show the tight fiscal stance maintained under the center-left 'Concertación' governments in Chile, and the successful reduction of inflation rates during the Alwyn and Frei periods. It is particularly noticeable that the Lagos administration established and strictly followed the now famous Chilean 'fiscal rule' and that the first Bachelet administration strengthened this institution, making it legally binding, and kept high surpluses during boom years (average 3\% of GDP, maximum around $6 \%$ ) in spite of high political pressures to weaken or abandon the rule. In contrast, the right-wing Piñera administration, that followed, engineered some weakening of the fiscal stance by changing the structural deficit goal and other parameters. ${ }^{56}$

These Tables also show that Presidents elected on populist platforms in Peru, such as Toledo and Humala (the latter claimed allegiance to Chavez in his first presidential candidacy), maintained fiscal balances under control and the lowest inflation rates in the region. As surprising, Alan García, who had presided over the most populist government in Peru during 1985-1990, leading to hyperinflation, a currency crisis and recession, in his recent term maintained fiscal surpluses and a low inflation rate.

\footnotetext{
55 A similar development took place in Europe after the Second World War, with the ascent to power of several former socialist parties, converted into social-democratic parties. These left-wing governments or coalitions increasingly adopted pro-market views on economic policies.

56 See an interview to Andrés Velasco on La Tercera concerning the Chilean fiscal rule under Sebastian Piñera's administration (2010).
} 
Even more impressive, the Evo Morales administrations in Bolivia kept the largest fiscal surpluses in the region, in sharp contrast not only to what its main ally and mentor (Chavez) did in Venezuela, but also to the outcomes under his center-right predecessors. The same has been the case with the Ortega administrations in Nicaragua. Fiscal and inflation outcomes also suggest that Correa in Ecuador did not shift towards excessively expansionary fiscal and monetary policies, in comparison to his predecessors.

These facts indicate that these 'orthodox' views on macroeconomic policies have become an entrenched conviction in Latin America, irrespective of the political inclinations of governing coalitions. Of course, there have been exceptions to this rule, such as the Chavez and Maduro regimes in Venezuela and, partially, the Cristina Fernandez government in Argentina ${ }^{57}$ (see below).

Most recent left-wing governments have also maintained relatively open trade policies, at least similar to those of their antecessors (Table 4 in the Web version of this paper), as well as prudent financial regulation and supervision, which avoided bankruptcies or credit crunches during the recent global financial crisis. ${ }^{58}$ In particular, the 'Concertación' administrations in Chile kept lower average effective tariffs than the Pinochet regime and engaged in negotiating a plethora of free trade agreements with developed and developing countries in most regions. Consequently, trade openness measures are the highest in Chile among LAC-7 and have continued to rise (see Table 5 in the Web version of this paper). Though other LAC-7 countries (with the exception of Mexico) maintain more restrictive trade policies than Chile (specially Brazil and Argentina), and show lower indexes of trade openness, the figures in Tables 4 and 5 do not indicate that left-wing regimes have been significantly more prone towards protectionism than their predecessors.

Reality checks may have played a significant role in these trends. Thus, for example, Lula may have been forced at the beginning of his first administration to nominate a very 'orthodox' economic team (in Finance and the Central Bank) to recover market confidence after the considerable volatility and capital flight that took place since the latter part of the

\footnotetext{
57 Argentina kept a tight fiscal stance during the Kirchner government and until 2009, but allowed a significant increase of the fiscal deficit from there onwards

${ }^{58}$ See Perry and Forero (2014).
} 
election, in spite of continued support by the MDI's ${ }^{59}$. Later on, he designated a more 'heterodox' Minister of Finance, but was keen in maintaining the significant autonomy that the Central Bank had enjoyed during Cardoso and Lula's first term, and kept fiscal policy within reasonable bounds.

Lula also kept the pro-market micro reforms of Cardoso (for example, with respect to openness to FDI and public-private partnerships in infrastructure), though he did not continued Cardoso's reformist drive in other micro issues, except on social policies (see below). Her successor, Dilma Rousseauf, was more prone to interventionist policies and fiscal expansion in her first term and, partly because of this, ran into serious market confidence problems since 2013 (see Figure 8), which together with a negative shock in terms of trade have brought Brasil to a deep recession (figure 11). These outcomes prompted her to nominate as Finance Minister a well-known 'orthodox' who immediately announced a sharp fiscal adjustment package. Political turmoil impeded its approval in Congress and Minister Levy had to resign.

Ortega, in Nicaragua, in spite of his close relations with Venezuela (which has provided significant financial support to Nicaragua), has followed strict macro policies and strongly promarket micro policies. He has indeed become the 'darling' of private investors in Central America. Such a dramatic shift from his earlier ideology and practices may either reflect a new conviction, after witnessing the economic failure of interventionist and expansionist policies during the Sandinista regime, or a pragmatic stance, given the CAFTA commitments and opportunities, and the obvious importance of large FDI and private investment flows for Nicaragua's growth.

As already mentioned, the Morales administrations macro orthodoxy is noteworthy. In spite of a very close relation with Venezuela, and initial left-wing and populist micro policies (his 'nationalization' of gas production and his attempts to impose agrarian reform in Santa Cruz and to take away royalties and autonomy from provinces), the Morales regime has applied the most austere fiscal and monetary policies in the region (highest fiscal surpluses and

\footnotetext{
${ }^{59}$ After major capital outflows at the end of the electoral campaign, the WB was actively trying to calm down markets and requested the IMF to extend the existing program one year in order to cover the transition, in an attempt to recover market confidence in Brazil.
} 
accumulation of international reserves -see Table 2 in the Web version of this paper and Figure 9), certainly much more orthodox that any of his predecessors.

Figure 8: LAC-7 EMBIs 2000-2015
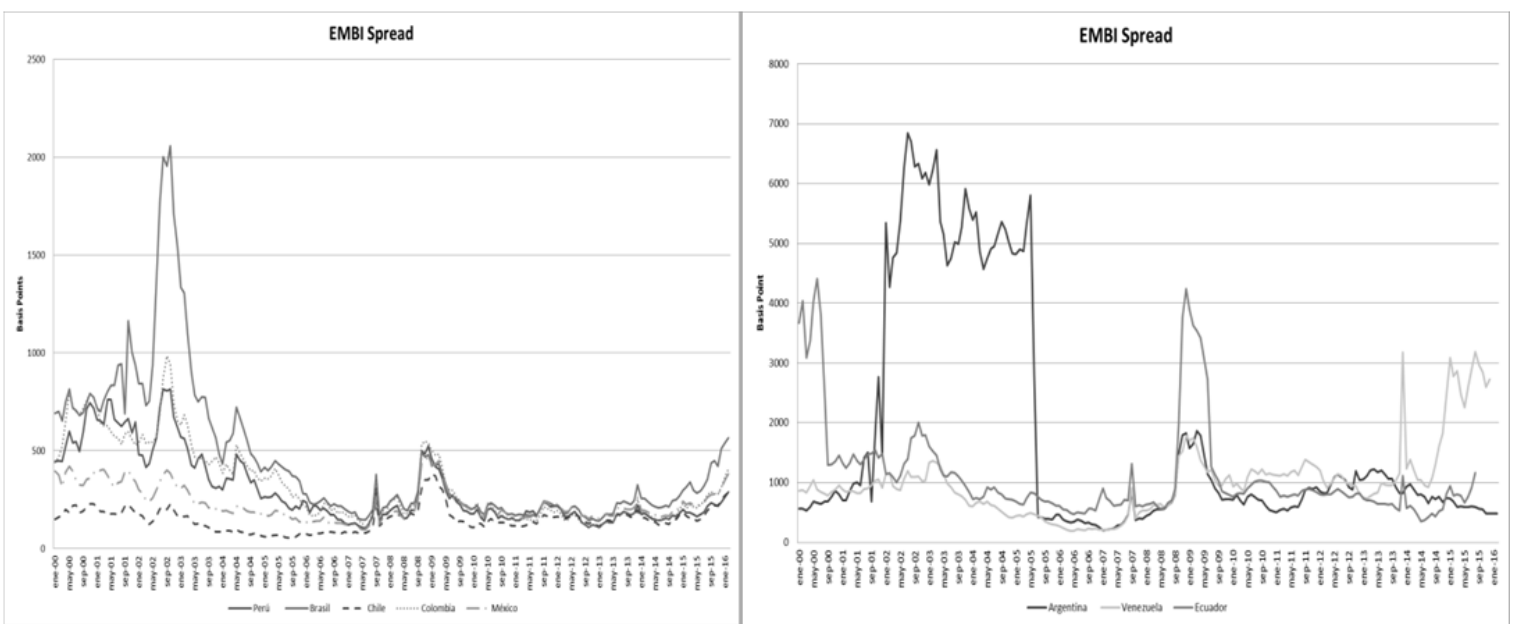

Source: JP Morgan.

In contrast with a relative convergence in macro-financial policies, there have been more differences among left-wing governments micro and social policies. In one extreme, since the return of democracy in Chile, the winning Center-Left coalition decided to maintain and deepen most of the pro-market macro, trade, financial and micro policies that had succeeded in delivering high growth and stability under the second half of the Pinochet dictatorship, but to complement them with aggressive and highly innovative social policies. Thus, the 'Concertacion' governments, in addition to the world-acclaimed 'fiscal-rule', developed the best financial sector regulation and supervision in the region, promoted more free-trade agreements than any other country in the region, implemented highly ambitious and welldesigned public-private partnerships in infrastructure, engaged in a second (and now a third) generation reform of its pioneering pension system and put in place an ambitious innovation system. At the same time, they have implemented successive ambitious educational and health reforms and the first program in the region attempting to eradicate extreme poverty (Chile Solidario). Though MDI's had little to do with most of these initiatives (or with those under the Pinochet regime), they were latter on adopted as part of their recommended 'package' of policies.

The Uruguay Frente Amplio administrations, and the Lula administrations in Brasil, considerably strengthened social policies and introduced innovations in them (such as Bolsa 
Familia and Primer Emprego in Brasil) ${ }^{60}$. However, although they maintained the pro market micro reforms of previous administrations, did not deepen them considerably. As mentioned, there has been some setback in several of these areas during the Rousseauf administration.

Figure 9: International Reserves/GDP: 2000-2015

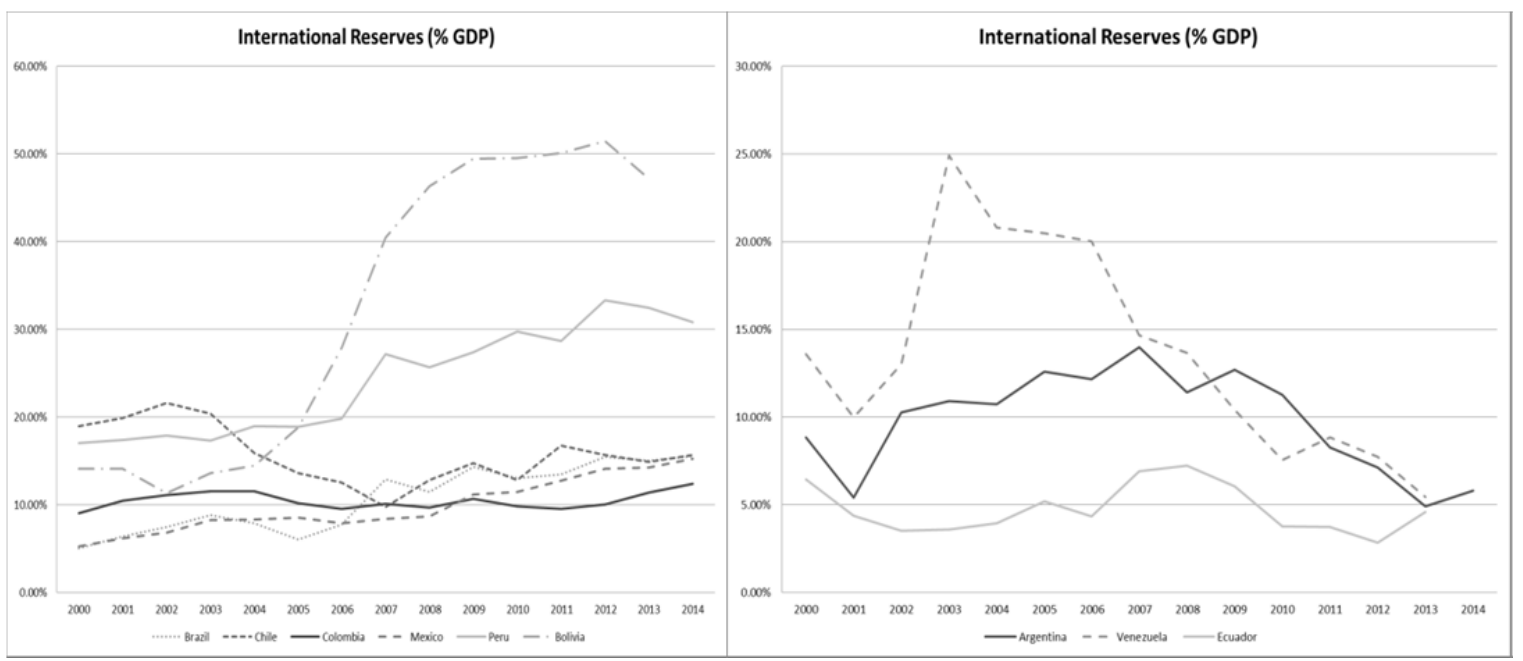

Source: World Development Indicators

All of these left-wing governments had very close and productive relations with the MDI's. This was in particular the case of the close collaboration between the World Bank and the first Lula Government. For example, the World Bank suggested to the Lula Government to institute an aggressive CCT program (Bolsa Familia, based on the expansion of the previous Bolsa Escolha) in lieu of a set of heavily interventionist social programs initially envisaged by the administration, and helped in designing and financing it.

Something very different happened in the Venezuelan case, and, to a lesser extent, in the Argentinian and Ecuadorean cases. The Chavez and Maduro governments had the largest deviations from 'orthodox' macro policies and pro-market micro policies. In spite of benefiting from the highest foreign exchange and fiscal boom in Venezuelan history (Figure 12) -due to the large increase in oil prices from 2003 to 2014-, Venezuela incurred in significant fiscal deficits during part of this period (Table 2 in the Web version of this paper), lost market access since 2009 (Figure 6) and ran out of international reserves (Figure 9), even while imposing strict capital controls and devaluing several times the official currency rate to the dollar (Figure 10), in spite of which the difference between the 'black' market and the

${ }^{60}$ Building on Bolsa Escolha, a more limited program instituted in some States during the Cardoso administration. 
official exchange rate sky-rocketed. In addition, Venezuela has had the highest inflation in the region (Table 3 in the Web version of this paper), as a consequence of a huge monetary expansion to finance the growing fiscal deficits, and the sharp devaluations of the currency.

Figure 10: Real Exchange Rates: 2000-2015

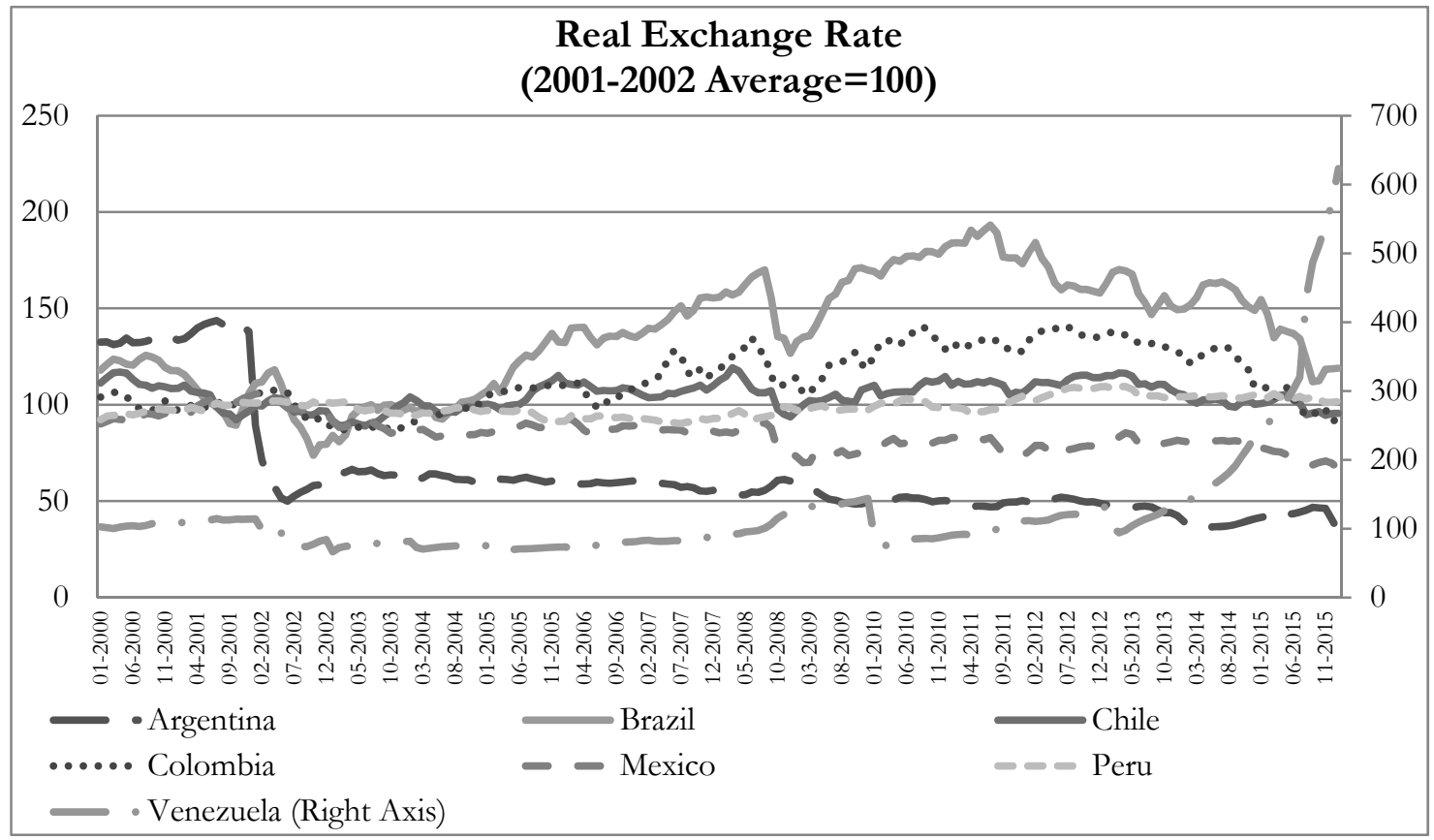

Source: Bank of International Settlements. Argentina was calculated using the official exchange rate.

Micro policies in Venezuela have been characterized by a strong anti-private sector and populist tone: expropriations (including supermarkets and cement factories), generalized price controls, severe restrictions on trade flows with neighboring Colombia, and so on. Though there has been significant expenditures in social programs (the so-called 'Misiones'), some of them have been questioned for corruption and ineffectiveness, and have used less public resources than the huge subsidies to gasoline prices and electricity that favor the higher middle classes and the rich. This combination of populist macro and micro policies led the country to a severe contraction, which began even before the fall in oil prices (Figure 11).

Argentinian micro-economic policies since 2000 show some similarities to those of Venezuela (expropriations, generalized tariff and price controls, export taxes and prohibitions, import restrictions), though not as extreme. Macro-financial management, however, remained very prudent until 2009. Indeed, low fiscal deficits (Table 2 in the Web version of this paper), limited monetary expansion and a competitive exchange rate (Table 3 in the Web version of this paper and Figure 10) permitted a fast recovery from the 1999-2002 crisis (Figure 11), in 
spite of the adverse effect of some micro policies. However, since 2009 fiscal deficits (Table 2 in the Web version of this paper) and inflation rates increased (Table 3 in the Web version of this paper), the country lost access to international capital markets (Figure 8) and the Central Bank lost reserves at a high speed (Figure 9), even before the fall in commodity prices, in spite of the imposition of capital controls. Consequently, there has been a more significant slowdown than in other countries in the region that were affected by more severe terms of trade shocks than those that Argentina suffered (Figure 12).

Figure 11: Growth rates by country

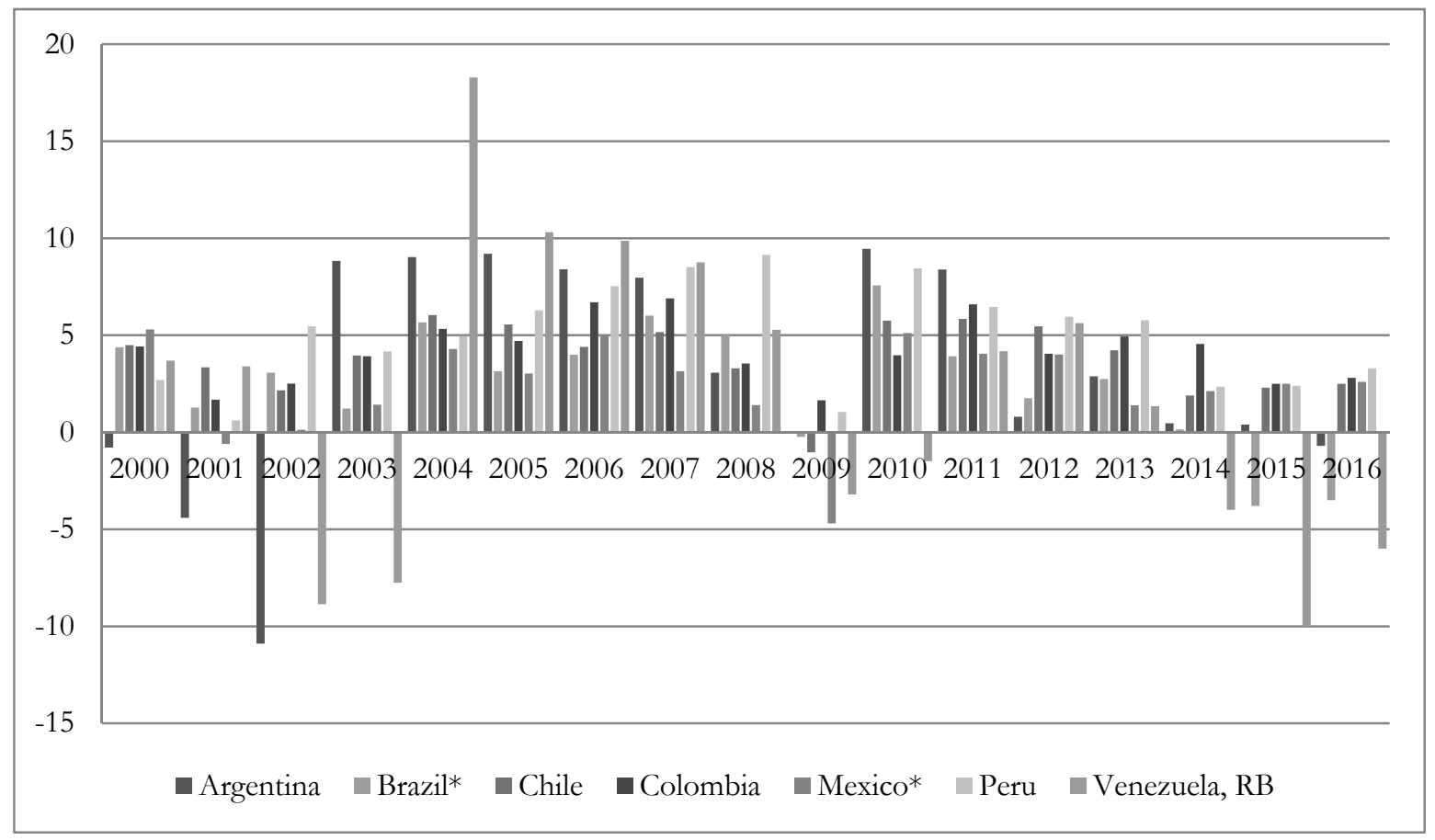

Source: Source: World Bank, WEO October 2014. *WEO Update 2016.

The significantly larger distortions in micro policies introduced by the Venezuelan and Argentinian governments are reflected in the weakening of indicators of institutional quality and cost of doing business in these countries (Figures 13 and 14). These figures also show the significant Chilean advantage over other Latin American countries in these indexes, thanks to the continuous process of pro-market micro reforms during the Concertación administrations.

This brief account suggest that the few governments that have engaged in openly populist macro and micro policies have eventually led their economies to output contractions, that the rest have so far avoided even while suffering similar adverse external shocks. It also 
illustrates the close and productive cooperation of MDI's with most of the recent left-wing governments in the region. In contrast, the relationship of MDI's (specially of the IMF and the WB) were more strained and less intense with the left-wing Governments of Argentina and Ecuador and, especially of Venezuela.

Figure 12. Terms of trade gains and shocks

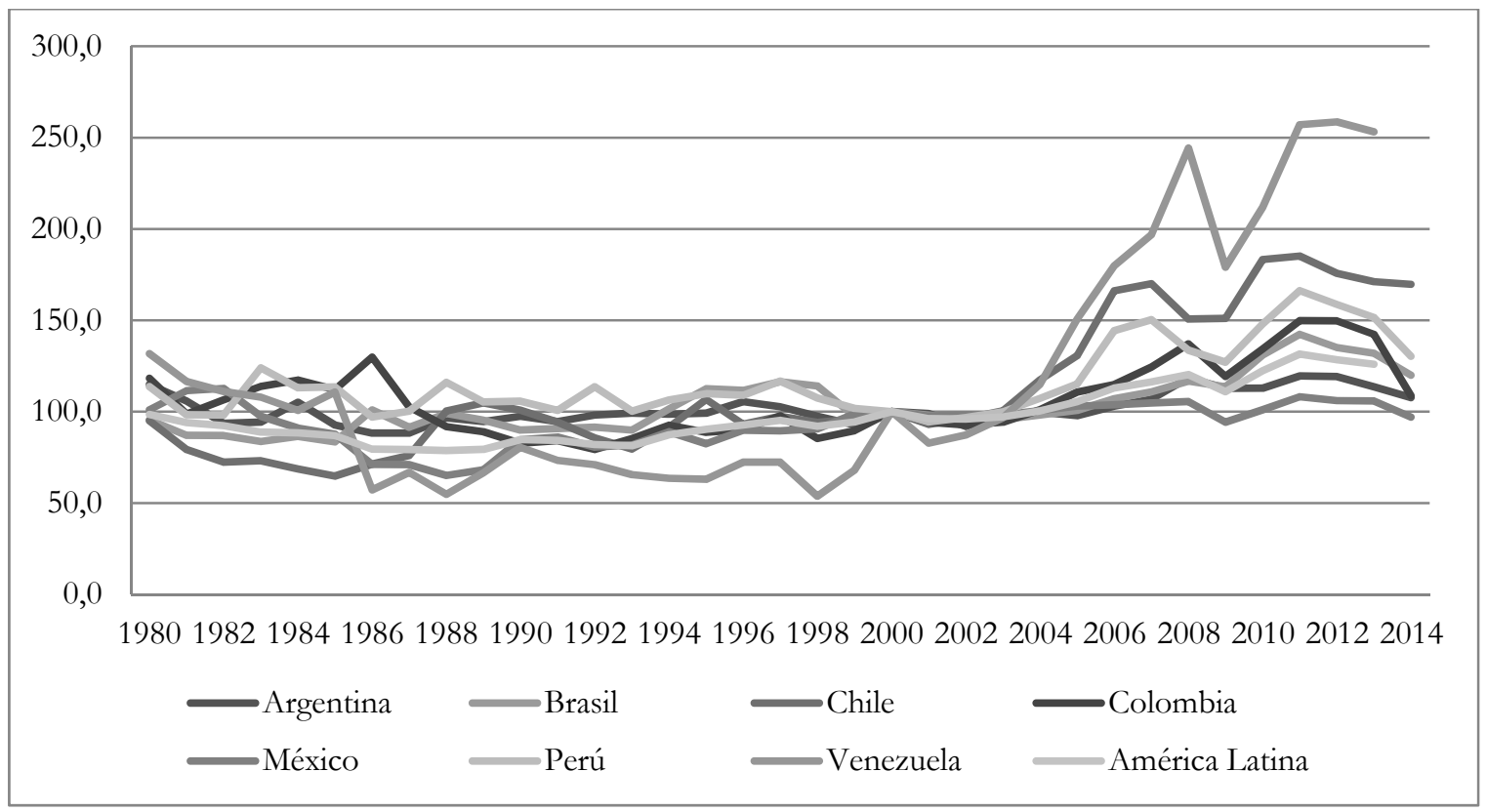

Source: World Development Indicators.

In these three cases the lack of a closer cooperation was as much a decision of the local Government, than of the IMF and the WB. The latter were clearly not supportive of Venezuelan populist macro and anti-private sector policies. In the cases of Argentina and Ecuador, there were some differences over macro policies, but other factors (expropriations and price controls, the Argentine hold outs and the aggressive Government public stance against the IMF and the WB) may have played a more important role. These three Governments, however, kept close and productive relations with IDB and, specially, with CAF, as lending figures show. Venezuela, and specially Ecuador, kept also a close relationship with FLAR (Argentina is not a member of FLAR). This indicates, once more, the importance of diversity in the MDI world and, in particular, the key rol played by regional MDI's as a complement of global MDI's. 
Figure 13: Governance Indicators

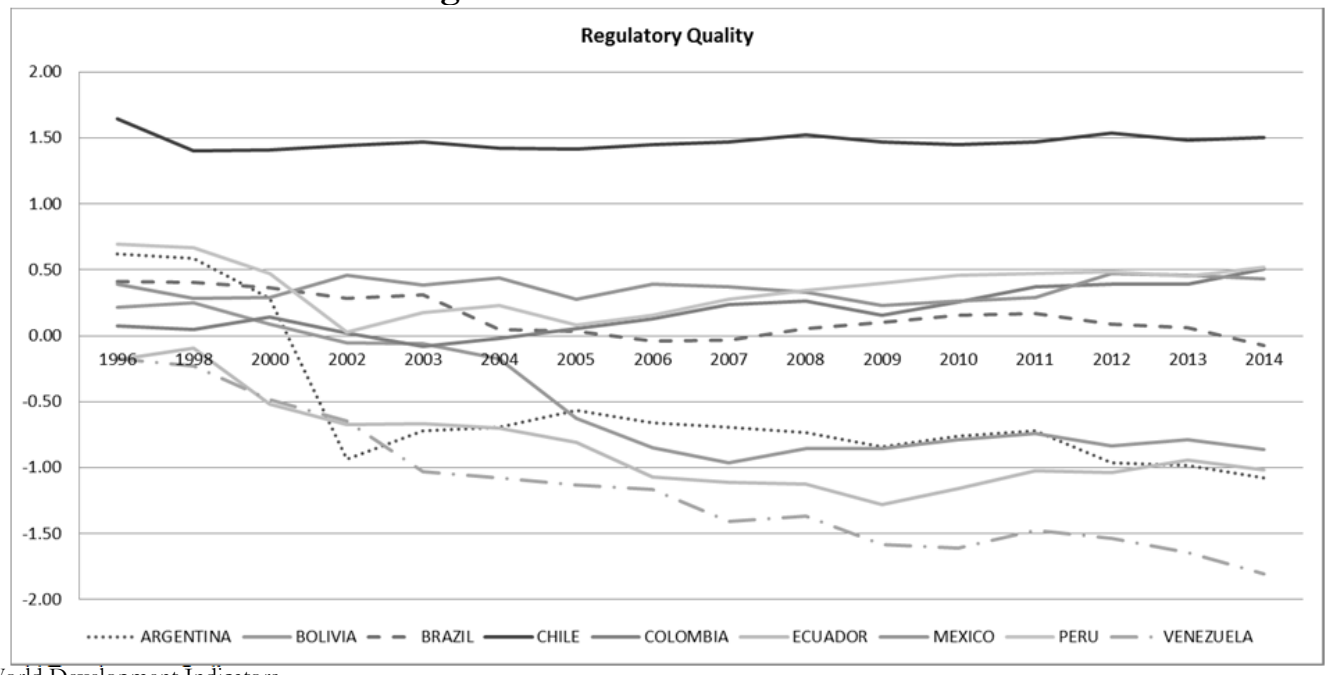

Source: World Development Indicators

Figure 14: Ease of Doing Business Ranking (189 countries)

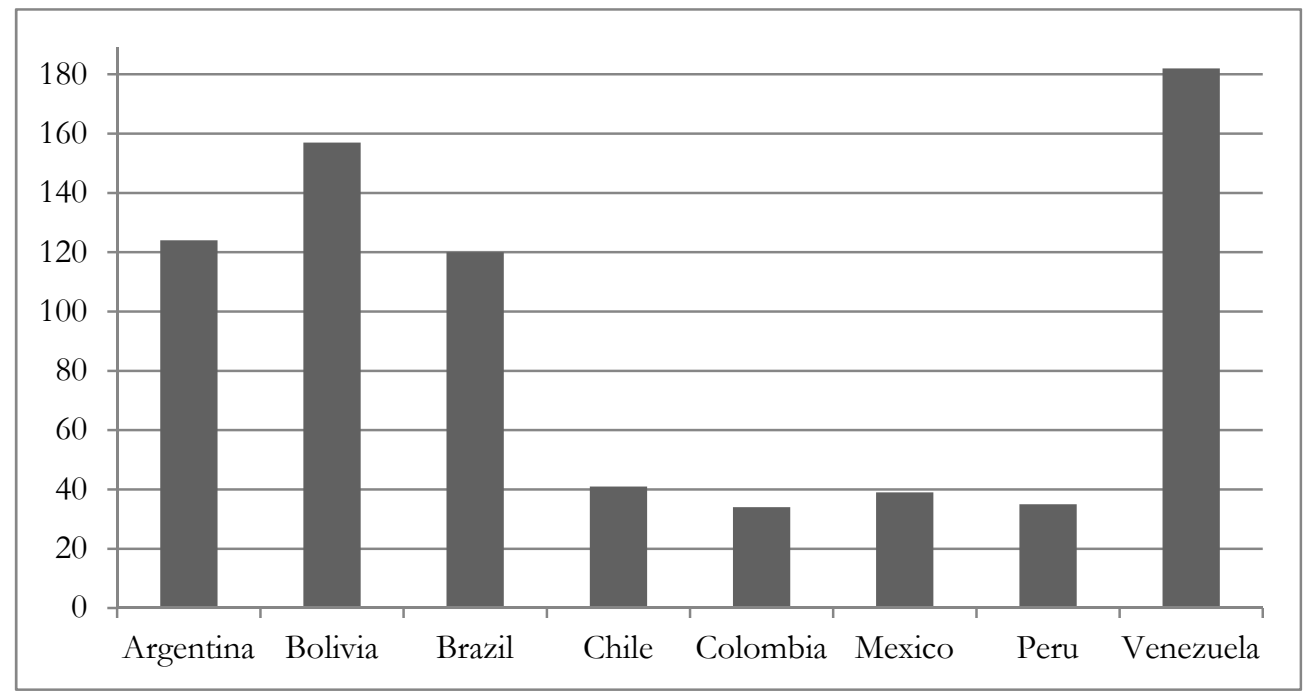

Source: Ease of Doing Business (2014)

\section{Conclusions}

This paper illustrates how many pro-market reforms were often the initiative of Latin American Governments, or at least resulted from shared views between them and the MDI's. In particular, it shows how left-wing governments in the region increasingly applied orthodox macro-economic policies (and some also pro-market micro-economic policies) and how they had close collaboration with MDI's and found it useful in the pursuit of their economic and social objectives. At the same time, it indicates how even strongly pro-market Governments 
often had serious confrontations with what they considered simplistic views from MDI's on important issues of policy.

Moreover, the paper documents how both Latin American governments and MDI's views on macroeconomic and development policies have changed considerably over time, with mutual influences along the way.

It also indicates how diversity of views on particular issues has also been common among MDI's themselves, and how regional MDI's (IDB, CAF and FLAR) have been more responsive to regional concerns and views and played an increasing role and influence within the international community.

Last but not least, the paper shows how the degree of influence of MDI's has naturally varied with the development of domestic and international private financial markets and countries access to them, as well as their cycles, among other factors. Influence was at its height during the Latin American debt crisis of the eighties, when most countries in the region lost access to international private capital markets, and have significantly declined since the early nineties, with short lived resurgences after the 1998 Russian crisis impact on capital flows reversals in the region and during the recent global financial crisis in 2009. It is likely to increase somewhat again in the current environment of lower terms of trade and capital inflows.

The landscape that emerges is, thus, more complex than a simple-minded division of the world between 'orthodox' and 'unorthodox' views or strategies, either among 'left-wing' or 'right-wing' governments, or among MDI's themselves. It is probably better described as a changing landscape with mutual influences between MDI's and regional views. 


\section{Bibliography}

Adler G. \& Tovar C. (2011), "Foreign Exchange Intervention: A Shield Against Appreciation Winds?”, International Monetary Fund.

Batini N., Breuer P., Kochhar K. \& Roger S. (2006), "Inflation Targeting and the IMF", Monetary and Financial Systems Department, Policy and Development Review Department, and Research Department, International Monetary Fund.

Blanchard O. \& Leigh D. (2013), "Growth Forecast Errors and Fiscal Multipliers," IMF Working Paper No. 13/1, WEO, 2010-2013.

Bova E., Carcenac N. \& Guerguil M. (2014), "Fiscal Rules and the Prociclicality of Fiscal Policy in the Developing World", International Monetary Fund.

Burki S. and Perry G., (1998), "Institutions Matter: Beyond the Washington Consensus", World Bank.

Calderon C. \& Serven L. (2010), "Infrastructure in Latin America", World Bank Policy Research Working Paper No. 5317.

Calvo G. (2008), "Crisis in Emerging Market Economies: A Global Perspective," K. Cowan, S. Edwards, and R. Valdes (editors), Current Account and External Financing; Santiago, Chile: Central Bank or Chile.

Coase R. (1960), "The Problem of Social Cost”, Journal of Law and Economics, Vol. 3. Oct., 1960, pp. 1-44.

Easterly W. \& Servén L. (2003), “The Limits of Stabilization : Infrastructure, Public Deficits, and Growth in Latin America", Latin American Development Forum, Palo Alto CA, Stanford University Press, Washington, DC, World Bank.

Ebeke C. \& Fouejieu A. (2015), "Inflation Targeting and Exchange Rate Regimes in Emerging Markets", IMF Working Paper, International Monetary Fund. 
Edwards S. \& Steiner R. (2008), “La revolución incompleta: Las reformas de Gaviria”, Grupo Editorial Norma, Fedesarrollo.

Engel E., Neilson C. \& Valdés R. (2011), "Chile’s Fiscal Rule as Social Insurance," Working Papers Central Bank of Chile 627, Central Bank of Chile.

Espinosa A. (1970), "Memoria de Hacienda 1966-1970”, Talleres Gráficos del Banco de la República, Bogotá.

Fiess N. (2004), "Chile's Fiscal Rule," Econometric Society 2004 Latin American Meetings 348, Econometric Society.

FLAR (2015), "Building a Latin American Reserve Fund: 35 Years of Flar". Fondo Latinoamericano de Reservas.

Forteza A., Tommasi M. \& Herrera G. (2006), "Understanding Reform in Latin America", Global Development Network Global Research Project on Understanding Reform: Synthesis of Country Studies from Latin America.

Frankel J. (2010), “Monetary policy in emerging markets: a survey”, NBER working paper.

Hausmann R. \& Rodrik D. (2003), "Economic Development as Self-Discovery”, Volume 72, Issue 2, December 2003, Pages 603-633 14th Inter-American Seminar on Economics.

Hausmann R., Talvi E., Gavin M., and R.Perotti (1996), "Managing Fiscal Policy in LAC: Volatility, Procyclicality and limited Creditworthiness", IADB.

Hirschman A. (1995), "Development Projects Observed" 4th Edition, the Brookings Institution. Washington D.C.

IDB (2007), "Living with Debt: How to Limit the Risks of Sovereign Finance, Economic and Social Progress in Latin America”, IDB Report, Inter-American Development Bank.

Independent Evaluation Office (2003), "Fiscal Adjustment in IMF-Supported Programs", Evaluation Report, Independent Evaluation Office, International Monetary Fund. 
Independent Evaluation Office (2004), “The IMF and Argentina, 1991-2001”, Evaluation Report, Independent Evaluation Office, International Monetary Fund.

Independent Evaluation Office (2013), "Fiscal Adjustment in IMF-Supported Programs", Evaluation Report, Independent Evaluation Office. International Monetary Fund.

International Monetary Fund (2015), "Peru: Staying the Course of PERU Economic Success", International Monetary Fund.

Junguito R. (2015), “El Fondo Monetario y el Banco de la Republica”, Mimeo, 2015.

Kaufmann D., Kray A. \& Mastruzzi M. (2010), “The Worldwide Governance Indicators: Methodology and Analytical Issues”, World Bank Policy Research Working Paper No. 5430

Klemm A. (2014), "Fiscal Policy in Latin America Over the Cycle", International Monetary Fund.

La Tercera (2010), “Andres Velasco: La administración Piñera 'optó por una senda de menor rigor fiscal que el gobierno anterior"”, latercera.com. Consultation Date: February 27 2016.

Lora E. (2000), “What Makes Reforms Likely? Timing and Sequencing of Structural Reforms in Latin America", Inter-American Development Bank.

North D. (1990), "Institutions, Institutional Change and Economic Performance”, Cambridge University Press.

Perry G. \& Forero A. (2014), “Latin America: The Day After. Is This Time Different?”, Center For Global Development Essay.

Perry G. \& Serven L. (2003), “The anatomy of a multiple crisis : Why was Argentina special and what can we learn from it?”, Research working paper series no. WPS 3081. Washington, DC. World Bank. 
Perry G. (2003), “Can Fiscal Rules Help Reduce Macroeconomic Volatility in the Latin America and the Caribbean Region”, Policy Research Working Paper 3080, The World Bank.

Perry G. (2009), "Beyond Lending How Multilateral Banks Can Help Developing Countries Manage Volatility" 1st Edition, Center for Global Development.

Perry G. (2016), "The role of regional multilateral institutions", LSE-CAF Conference on Global Governance, January 2016.

Perry G., Serven L. \& Suescun R. (2004), "Prudence or Abstinence? Fiscal policy, stabilization and growth”, World Bank.

Perry G. (2011), “Growing Business or Development Priority? Multilateral Development Banks' Direct Support to Private Firms”, CGD Report, Center for Global Development.

Stiglitz J. (2002), “Globalization and Its Discontents”, Norton Paperback.

Stiglitz J. (2006), “Making Globalization Work”, W.W. Norton and Company.

Talvi E. \& Vegh C. (2005), "Tax Base Variability And Procyclical Fiscal Policy In Developing Countries", Journal of Development Economics, 2005, v78(1,Oct), 156-190.

Vegh C., Calvo G. \& Reinhart C. (1994), "Targeting the Real Exchange Rate: Theory and Evidence," IMF Working Papers 94/22, International Monetary Fund.

Williamson J. (2004), “A Short History of the Washington Consensus”, From the Washington Consensus towards a new Global Governance, Fundación CIDOB, Barcelona.

World Bank (1995), "World Development Report: Workers in an Integrated World", The World Bank. 


\section{Online Version Annex: Tables}

Table 1 Cyclical performance of IMF and MDB disbursements

\begin{tabular}{|c|c|c|c|c|c|c|}
\hline & \multicolumn{6}{|c|}{ Prociclicality with GDP Growth } \\
\hline & \multicolumn{3}{|c|}{ Correlation Coefficients } & \multicolumn{3}{|c|}{ Linear Regression Coefficients } \\
\hline & $\begin{array}{c}\text { Development } \\
\text { Banks }\end{array}$ & IMF & Total & $\begin{array}{c}\text { Development } \\
\text { Banks }\end{array}$ & IMF & Total \\
\hline Argentina & 0,3996 & $-0,0384$ & 0,2702 & $14.1003 * * *$ & $-1.3552^{* * *}$ & $7.1326 * * *$ \\
\hline Brazil & 0,0884 & $-0,2307$ & $-0,0564$ & $1.6854 * * *$ & $-6.8437 * * *$ & $-1.0128 * * *$ \\
\hline Colombia & 0,0428 & N.A. & 0,0428 & 0.5635 & 0.0000 & 0.5635 \\
\hline Mexico & $-0,1125$ & $-0,3901$ & $-0,2559$ & -3.4760 & $-16.7588^{* * *}$ & $-5.1474 * * *$ \\
\hline Peru & $-0,2977$ & $-0,0654$ & $-0,3300$ & -6.2867 & $-5.9669 * * *$ & $-7.3534 * * *$ \\
\hline Venezuela & 0,1312 & $-0,1015$ & 0,0545 & 4.1642 & $-5.4120 * * *$ & 1.3331 \\
\hline Total & $-0,0840$ & $-0,4772$ & $-0,3038$ & -1.7869 & $-14.2555^{* * *}$ & $-4.6332 * * *$ \\
\hline
\end{tabular}

Prociclicality with Capital Flows

\begin{tabular}{lcccccc}
\hline & \multicolumn{2}{c}{ Correlation Coefficients } & \multicolumn{2}{c}{ Linear Regression Coefficients } \\
& $\begin{array}{c}\text { Development } \\
\text { Banks }\end{array}$ & IMF & Total & $\begin{array}{c}\text { Development } \\
\text { Banks }\end{array}$ & IMF & Total \\
Argentina & 0,1226 & $-0,5159$ & $-0,2864$ & $1,78 \mathrm{E}-06$ & $-7,59 \mathrm{E}-06$ & $-5,81 \mathrm{E}-06$ \\
\hline Brazil & $-0,4959$ & $-0,2002$ & $-0,6089$ & $-3,22 \mathrm{E}-06$ & $-8,42 \mathrm{E}-07$ & $-4,07 \mathrm{E}-06$ \\
Colombia & $-0,1838$ & N.A. & $-0,1838$ & $-7,75 \mathrm{E}-06$ & 0 & $-7,75 \mathrm{E}-06$ \\
Mexico & $-0,4305$ & $-0,6379$ & $-0,5775$ & $-3,59 \mathrm{E}-06$ & $-3,87 \mathrm{E}-06$ & $-7,46 \mathrm{E}-06$ \\
Peru & 0,1077 & $-0,0938$ & 0,0909 & $1,15 \mathrm{E}-05$ & $-2,48 \mathrm{E}-06$ & $9,06 \mathrm{E}-06$ \\
\hline Venezuela & $-0,2333$ & $-0,2419$ & $-0,2923$ & $-1,43 \mathrm{E}-05$ & $-8,89 \mathrm{E}-06$ & $-2,32 \mathrm{E}-05$ \\
\hline Total & $-0,4757$ & $-0,5842$ & $-0,6532$ & $-8,81 \mathrm{E}-07$ & $-7,51 \mathrm{E}-07$ & $-1,63 \mathrm{E}-06$ \\
\hline
\end{tabular}


Table 2. Average fiscal deficits in Latin America by periods of Governments (\% GDP) (1990-2014)

\begin{tabular}{|c|c|c|c|c|c|c|}
\hline Argentina & $\begin{array}{c}\text { C.S. Menem } \\
\text { (1989-1999) } \\
-2,29 \\
\end{array}$ & $\begin{array}{c}\text { R. de la Rúa } \\
\text { (1999-2001) } \\
-3,80 \\
\end{array}$ & $\begin{array}{c}\text { E. Duhalde } \\
\text { (2001-2003) } \\
-1,66 \\
\end{array}$ & $\begin{array}{c}\text { N. Kirchner } \\
(2003-2007) \\
1,73 \\
\end{array}$ & $\begin{array}{c}\text { C. Kirchner } \\
\text { (2007-2014) } \\
-1,18 \\
\end{array}$ & \\
\hline Brazil* & $\begin{array}{c}\text { F. Collor } \\
\text { (1990-1992) } \\
-1.34\end{array}$ & $\begin{array}{c}\text { I. Franco } \\
\text { (1992-1994) } \\
-4.10\end{array}$ & $\begin{array}{c}\text { F. H. Cardoso } \\
\text { (1995-2002) } \\
-1.51\end{array}$ & $\begin{array}{c}\text { L. I. Lula } \\
\text { (2003-2010) } \\
-2.57\end{array}$ & $\begin{array}{c}\text { D. Rousseff } \\
\text { (2011-2014) } \\
-3.39\end{array}$ & \\
\hline Chile & $\begin{array}{c}\text { P. Aylwin } \\
\mathbf{( 1 9 9 0 - 1 9 9 4 )} \\
1,79 \\
\end{array}$ & $\begin{array}{c}\text { E. Frei } \\
\text { (1994-2000) } \\
0,92 \\
\end{array}$ & $\begin{array}{c}\text { R. Lagos } \\
(2000-2006) \\
1,61 \\
\end{array}$ & $\begin{array}{c}\text { M. Bachelet } \\
\text { (2006-2010) } \\
3,01 \\
\end{array}$ & $\begin{array}{c}\text { S. Piñera } \\
\text { (2010-2013) } \\
0,31 \\
\end{array}$ & \\
\hline Colombia & $\begin{array}{c}\text { C. Gaviria } \\
\mathbf{( 1 9 9 0 - 1 9 9 4 )} \\
-0,10 \\
\end{array}$ & $\begin{array}{c}\text { E. Samper } \\
\text { (1994-1998) } \\
-2,15 \\
\end{array}$ & $\begin{array}{c}\text { A. Pastrana } \\
(1998-2002) \\
-3,70 \\
\end{array}$ & $\begin{array}{c}\text { A. Uribe } \\
(2002-2010) \\
-1,73 \\
\end{array}$ & $\begin{array}{c}\text { J.M. Santos } \\
\text { (2010-2014) } \\
-1,51 \\
\end{array}$ & \\
\hline Mexico & $\begin{array}{c}\text { C. Salinas } \\
\text { (1988-1994) } \\
-0,81 \\
\end{array}$ & $\begin{array}{c}\text { E. Zedillo } \\
\text { (1994-2000) } \\
-4,22 \\
\end{array}$ & $\begin{array}{c}\text { V. Fox } \\
(2000-2006) \\
-2,17 \\
\end{array}$ & $\begin{array}{c}\text { F. Calderon } \\
(\mathbf{2 0 0 6 - 2 0 1 2 )} \\
-2,78 \\
\end{array}$ & $\begin{array}{c}\text { E. Peña } \\
(2006-2014) \\
-3,10 \\
\end{array}$ & \\
\hline Peru & $\begin{array}{c}\text { A. Fujimori } \\
(\mathbf{1 9 9 0 - 2 0 0 0 )} \\
-2,09 \\
\end{array}$ & $\begin{array}{c}\text { V. Paniagua } \\
\text { (2000-2001) } \\
-2,11 \\
\end{array}$ & $\begin{array}{c}\text { A. Toledo } \\
(2001-2006) \\
-0,76 \\
\end{array}$ & $\begin{array}{c}\text { A. Garcia } \\
\mathbf{( 2 0 0 6 - 2 0 1 1 )} \\
1,44 \\
\end{array}$ & $\begin{array}{c}\text { O. Humala } \\
(2013-2014) \\
0,30 \\
\end{array}$ & \\
\hline Venezuela & $\begin{array}{c}\text { C. Perez } \\
\text { (1989-1993) } \\
-1,73\end{array}$ & $\begin{array}{c}\text { R. Caldera } \\
\begin{array}{c}(1994-1999) \\
-1,71\end{array}\end{array}$ & $\begin{array}{c}\text { H. Chavez } \\
\text { (1999-2013) } \\
-4,25\end{array}$ & $\begin{array}{c}\text { N. Maduro } \\
\text { (2013-2014) } \\
-14,67\end{array}$ & & \\
\hline Ecuador & $\begin{array}{c}\text { S.Durán } \\
\text { (1992-1996) } \\
-0,76\end{array}$ & $\begin{array}{c}\text { J. Mahuad } \\
\text { (1998-2000) } \\
-2,15\end{array}$ & $\begin{array}{c}\text { G.Noboa } \\
(\mathbf{2 0 0 0 - 2 0 0 3 )} \\
0,96\end{array}$ & $\begin{array}{c}\text { L. Gutierrez } \\
\text { (2003-2005) } \\
1,19\end{array}$ & $\begin{array}{c}\text { A. Palacio } \\
(2005-2007) \\
1,75\end{array}$ & $\begin{array}{c}\text { R. Correa } \\
\text { (2007-2014) } \\
-1,67\end{array}$ \\
\hline Bolivia & $\begin{array}{c}\text { J.Paz } \\
\text { (1989-1993) } \\
-4,92\end{array}$ & $\begin{array}{c}\text { G. Sanchez } \\
\text { (1993-1997) } \\
-3,22\end{array}$ & $\begin{array}{c}\text { H. Banzer } \\
\text { (1997-2001) } \\
-4,55\end{array}$ & $\begin{array}{c}\text { C. Mesa } \\
\text { (2003-2005) } \\
-5,22\end{array}$ & $\begin{array}{c}\text { E. } \\
\text { Rodriguez } \\
(2005-2006) \\
1,11\end{array}$ & $\begin{array}{c}\text { E. Morales } \\
(\mathbf{2 0 0 6 - 2 0 1 4 )} \\
1,27\end{array}$ \\
\hline
\end{tabular}


Table 3. Average inflation rates in Latin America by periods of Governments (19902015)

\begin{tabular}{|c|c|c|c|c|c|c|}
\hline Argentina & $\begin{array}{c}\text { C.S. Menem } \\
\text { (1989-1999) } \\
479,98\end{array}$ & $\begin{array}{c}\text { R. de la Rúa } \\
\text { (1999-2001) } \\
-0,63\end{array}$ & $\begin{array}{c}\text { E. Duhalde } \\
\text { (2001-2003) } \\
13,32\end{array}$ & $\begin{array}{c}\text { N. Kirchner } \\
(\mathbf{2 0 0 3 - 2 0 0 7 )} \\
16,95\end{array}$ & $\begin{array}{c}\text { C. Kirchner* } \\
\text { (2007-2014) } \\
23.14\end{array}$ & \\
\hline Brazil & $\begin{array}{c}\text { F. Collor } \\
\mathbf{( 1 9 9 0 - 1 9 9 2 )} \\
1360,95\end{array}$ & $\begin{array}{c}\text { I. Franco } \\
\text { (1992-1994) } \\
1757,46\end{array}$ & $\begin{array}{c}\text { F. H. Cardoso } \\
\mathbf{( 1 9 9 5 - 2 0 0 2 )} \\
19,26\end{array}$ & $\begin{array}{c}\begin{array}{c}\text { L. I. Lula } \\
(2003-2010) \\
8,39\end{array}\end{array}$ & $\begin{array}{c}\text { D. Rousseff } \\
\text { (2011-2014) } \\
6,90\end{array}$ & \\
\hline Chile & $\begin{array}{c}\text { P. Aylwin } \\
\text { (1990-1994) } \\
16,65\end{array}$ & $\begin{array}{c}\text { E. Frei } \\
\text { (1994-2000) } \\
6,54\end{array}$ & $\begin{array}{c}\text { R. Lagos } \\
\mathbf{( 2 0 0 0 - 2 0 0 6 )} \\
7,43\end{array}$ & $\begin{array}{c}\text { M. Bachelet } \\
\text { (2006-2010) } \\
6,16\end{array}$ & $\begin{array}{c}\text { S. Piñera } \\
\text { (2010-2013) } \\
3,71\end{array}$ & \\
\hline Colombia & $\begin{array}{c}\text { C. Gaviria } \\
(1990-1994) \\
29,57\end{array}$ & $\begin{array}{c}\text { E. Samper } \\
(\mathbf{1 9 9 4 - 1 9 9 8 )} \\
22,54\end{array}$ & $\begin{array}{c}\text { A. Pastrana } \\
\text { (1998-2002) } \\
14,33\end{array}$ & $\begin{array}{c}\begin{array}{c}\text { A. Uribe } \\
(2002-2010)\end{array} \\
5,70\end{array}$ & $\begin{array}{c}\text { J.M. Santos } \\
\text { (2010-2014) } \\
3,46\end{array}$ & \\
\hline Mexico & $\begin{array}{c}\text { C. Salinas } \\
\text { (1988-1994) } \\
22,44\end{array}$ & $\begin{array}{c}\text { E. Zedillo } \\
\text { (1994-2000) } \\
18,63\end{array}$ & $\begin{array}{c}\text { V. Fox } \\
(2000-2006) \\
6,83\end{array}$ & $\begin{array}{c}\text { F. Calderon } \\
\text { (2006-2012) } \\
4,83\end{array}$ & $\begin{array}{c}\text { E. Peña } \\
\text { (2006-2014) } \\
4,34\end{array}$ & \\
\hline Peru & $\begin{array}{c}\text { A. Fujimori } \\
\mathbf{( 1 9 9 0 - 2 0 0 0 )} \\
620,78\end{array}$ & $\begin{array}{c}\text { V. Paniagua } \\
\text { (2000-2001) } \\
2,43\end{array}$ & $\begin{array}{c}\text { A. Toledo } \\
\text { (2001-2006) } \\
3,40\end{array}$ & $\begin{array}{c}\text { A. Garcia } \\
\text { (2006-2011) } \\
4,23\end{array}$ & $\begin{array}{c}\text { O. Humala } \\
\text { (2013-2014) } \\
2,32\end{array}$ & \\
\hline Venezuela & $\begin{array}{c}\text { C. Perez } \\
\text { (1989-1993) } \\
42,35\end{array}$ & $\begin{array}{c}\text { R. Caldera } \\
\text { (1994-1999) } \\
52,28\end{array}$ & $\begin{array}{c}\text { H. Chavez } \\
\text { (1999-2013) } \\
26,01\end{array}$ & $\begin{array}{c}\text { N. Maduro } \\
\text { (2013-2014) } \\
42,07\end{array}$ & & \\
\hline Ecuador & $\begin{array}{c}\text { S.Durán } \\
\text { (1992-1996) } \\
5,73\end{array}$ & 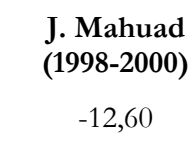 & $\begin{array}{c}\text { G.Noboa } \\
\mathbf{( 2 0 0 0 - 2 0 0 3 )} \\
10,93\end{array}$ & $\begin{array}{c}\text { L. Gutierrez } \\
\text { (2003-2005) } \\
7,53\end{array}$ & $\begin{array}{c}\text { A. Palacio } \\
\text { (2005-2007) } \\
7,46\end{array}$ & $\begin{array}{c}\text { R. Correa } \\
\text { (2007-2014) } \\
5,61\end{array}$ \\
\hline Bolivia & $\begin{array}{c}\text { J.Paz } \\
\mathbf{( 1 9 8 9 - 1 9 9 3 )} \\
13,38\end{array}$ & $\begin{array}{c}\text { G. Sanchez } \\
\text { (1993-1997) } \\
8,64\end{array}$ & $\begin{array}{c}\text { H. Banzer } \\
(1997-2001) \\
4,45\end{array}$ & $\begin{array}{c}\text { C. Mesa } \\
(2003-2005) \\
6,75\end{array}$ & $\begin{array}{c}\text { E. } \\
\text { Rodriguez } \\
\text { (2005-2006) } \\
9,80\end{array}$ & $\begin{array}{c}\text { E. Morales } \\
\text { (2006-2014) } \\
7,91\end{array}$ \\
\hline
\end{tabular}


Table 4. Average Tariff Rate by Government in LA (1990-2014)

\begin{tabular}{|c|c|c|c|c|c|c|}
\hline \multirow{2}{*}{ Argentina } & $\begin{array}{c}\text { C.S. Menem } \\
(1989-1999)\end{array}$ & $\begin{array}{c}\text { R. de la Rúa } \\
\text { (1999-2001) }\end{array}$ & $\begin{array}{l}\text { E. Duhalde } \\
(2001-2003)\end{array}$ & $\begin{array}{l}\text { N. Kirchner } \\
(2003-2007)\end{array}$ & $\begin{array}{l}\text { C. Kirchner } \\
(2007-2014)\end{array}$ & \\
\hline & 14,40 & 14,54 & 14,25 & 11,74 & 10,97 & \\
\hline \multirow{2}{*}{ Brazil } & $\begin{array}{c}\text { F. Collor } \\
(1990-1992)\end{array}$ & $\begin{array}{l}\text { I. Franco } \\
(1992-1994)\end{array}$ & $\begin{array}{c}\text { F. H. Cardoso } \\
(1995-2002)\end{array}$ & $\begin{array}{c}\text { L. I. Lula } \\
(2003-2010)\end{array}$ & $\begin{array}{l}\text { D. Rousseff } \\
\text { (2011-2014) }\end{array}$ & \\
\hline & 28.20 & 20.30 & 15,21 & 13,06 & 13,66 & \\
\hline \multirow{2}{*}{ Chile } & $\begin{array}{l}\text { P. Aylwin } \\
(1990-1994)\end{array}$ & $\begin{array}{c}\text { E. Frei } \\
(1994-2000)\end{array}$ & $\begin{array}{l}\text { R. Lagos } \\
(2000-2006)\end{array}$ & $\begin{array}{l}\text { M. Bachelet } \\
(2006-2010)\end{array}$ & $\begin{array}{l}\text { S. Piñera } \\
(2010-2013)\end{array}$ & \\
\hline & 10,99 & 10,44 & 6,00 & 3,28 & 3,78 & \\
\hline \multirow{2}{*}{ Colombia } & $\begin{array}{l}\text { C. Gaviria } \\
(1990-1994)\end{array}$ & $\begin{array}{l}\text { E. Samper } \\
(1994-1998)\end{array}$ & $\begin{array}{c}\text { A. Pastrana } \\
(1998-2002)\end{array}$ & $\begin{array}{c}\text { A. Uribe } \\
(2002-2010)\end{array}$ & $\begin{array}{l}\text { J.M. Santos } \\
\text { (2010-2014) }\end{array}$ & \\
\hline & 10,16 & 12,72 & 12,45 & 11,33 & 7,30 & \\
\hline \multirow{2}{*}{ Mexico } & $\begin{array}{l}\text { C. Salinas } \\
(1988-1994)\end{array}$ & $\begin{array}{l}\text { E. Zedillo } \\
(1994-2000)\end{array}$ & $\begin{array}{c}\text { V. Fox } \\
(2000-2006)\end{array}$ & $\begin{array}{l}\text { F. Calderon } \\
(2006-2012)\end{array}$ & $\begin{array}{c}\text { E. Peña } \\
(2006-2014)\end{array}$ & \\
\hline & 14,29 & 15,19 & 13,90 & 7,02 & 7,02 & \\
\hline \multirow{2}{*}{ Peru } & $\begin{array}{l}\text { A. Fujimori } \\
(1990-2000)\end{array}$ & $\begin{array}{c}\text { V. Paniagua } \\
(2000-2001)\end{array}$ & $\begin{array}{l}\text { A. Toledo } \\
(2001-2006)\end{array}$ & $\begin{array}{l}\text { A. Garcia } \\
(2006-2011)\end{array}$ & $\begin{array}{l}\text { O. Humala } \\
\text { (2013-2014) }\end{array}$ & \\
\hline & 14,46 & 13,20 & 9,14 & 5,46 & 2,88 & \\
\hline \multirow{2}{*}{ Venezuela } & $\begin{array}{c}\text { C. Perez } \\
(1989-1993)\end{array}$ & $\begin{array}{l}\text { R. Caldera } \\
(1994-1999)\end{array}$ & $\begin{array}{l}\text { H. Chavez } \\
(1999-2013)\end{array}$ & $\begin{array}{l}\text { N. Maduro } \\
\text { (2013-2014) }\end{array}$ & & \\
\hline & 17,14 & 12,98 & 12,48 & 11,65 & & \\
\hline \multirow{2}{*}{ Ecuador } & $\begin{array}{l}\text { S.Durán } \\
(1992-1996)\end{array}$ & $\begin{array}{l}\text { J. Mahuad } \\
(1998-2000)\end{array}$ & $\begin{array}{l}\text { G.Noboa } \\
(2000-2003)\end{array}$ & $\begin{array}{l}\text { L. Gutierrez } \\
(2003-2005)\end{array}$ & $\begin{array}{l}\text { A. Palacio } \\
(2005-2007)\end{array}$ & $\begin{array}{c}\text { R. Correa } \\
(2007-2014)\end{array}$ \\
\hline & 11,35 & 12,76 & 12,02 & 11,71 & 10,56 & 8,67 \\
\hline \multirow[t]{2}{*}{ Bolivia } & $\begin{array}{c}\text { J.Paz } \\
(1989-1993)\end{array}$ & $\begin{array}{l}\text { G. Sanchez } \\
(1993-1997)\end{array}$ & $\begin{array}{r}\text { H. Banzer } \\
(1997-2001)\end{array}$ & $\begin{array}{c}\text { C. Mesa } \\
(2003-2005)\end{array}$ & $\begin{array}{c}\text { E. } \\
\text { Rodriguez } \\
(2005-2006)\end{array}$ & $\begin{array}{l}\text { E. Morales } \\
(2006-2014)\end{array}$ \\
\hline & 9,73 & 9,72 & 9,44 & 7,48 & 6,84 & 7,99 \\
\hline
\end{tabular}


Table 5: Average Trade Openness during governmental periods

\begin{tabular}{|c|c|c|c|c|c|c|}
\hline \multirow{2}{*}{ Argentina } & $\begin{array}{c}\text { C.S. Menem } \\
(1989-1999)\end{array}$ & $\begin{array}{l}\text { R. de la Rúa } \\
\text { (1999-2001) }\end{array}$ & $\begin{array}{l}\text { E. Duhalde } \\
(2001-2003)\end{array}$ & $\begin{array}{l}\text { N. Kirchner } \\
(2003-2007)\end{array}$ & $\begin{array}{l}\text { C. Kirchner } \\
(2007-2014)\end{array}$ & \\
\hline & 18.80 & 21.95 & 34.75 & 37.23 & 31.93 & \\
\hline \multirow{2}{*}{ Brazil } & $\begin{array}{l}\text { F. Collor } \\
(1990-1992)\end{array}$ & $\begin{array}{l}\text { I. Franco } \\
(1992-1994)\end{array}$ & $\begin{array}{c}\text { F. H. Cardoso } \\
(1995-2002)\end{array}$ & $\begin{array}{c}\text { L. I. Lula } \\
(2003-2010)\end{array}$ & $\begin{array}{l}\text { D. Rousseff } \\
(2011-2014)\end{array}$ & \\
\hline & 17.00 & 19.40 & 20.39 & 26.02 & 25.29 & \\
\hline \multirow{2}{*}{ Chile } & $\begin{array}{l}\text { P. Aylwin } \\
(1990-1994)\end{array}$ & $\begin{array}{c}\text { E. Frei } \\
(1994-2000)\end{array}$ & $\begin{array}{l}\text { R. Lagos } \\
(2000-2006)\end{array}$ & $\begin{array}{l}\text { M. Bachelet } \\
(2006-2010)\end{array}$ & $\begin{array}{l}\text { S. Piñera } \\
(2010-2013)\end{array}$ & \\
\hline & 58.55 & 56.34 & 65.22 & 73.05 & 69.24 & \\
\hline \multirow{2}{*}{ Colombia } & $\begin{array}{l}\text { C. Gaviria } \\
(1990-1994)\end{array}$ & $\begin{array}{l}\text { E. Samper } \\
(1994-1998)\end{array}$ & $\begin{array}{l}\text { A. Pastrana } \\
(1998-2002)\end{array}$ & $\begin{array}{c}\text { A. Uribe } \\
(2002-2010)\end{array}$ & $\begin{array}{l}\text { J.M. Santos } \\
(2010-2014)\end{array}$ & \\
\hline & 35.04 & 35.79 & 34.32 & 35.73 & 37.21 & \\
\hline \multirow{2}{*}{ Mexico } & $\begin{array}{l}\text { C. Salinas } \\
(1988-1994)\end{array}$ & $\begin{array}{l}\text { E. Zedillo } \\
(1994-2000)\end{array}$ & $\begin{array}{c}\text { V. Fox } \\
(2000-2006)\end{array}$ & $\begin{array}{l}\text { F. Calderon } \\
(2006-2012)\end{array}$ & $\begin{array}{c}\text { E. Peña } \\
(2006-2014)\end{array}$ & \\
\hline & 33.80 & 47.38 & 52.35 & 59.81 & 61.05 & \\
\hline \multirow{2}{*}{ Peru } & $\begin{array}{l}\text { A. Fujimori } \\
(1990-2000)\end{array}$ & $\begin{array}{l}\text { V. Paniagua } \\
(2000-2001)\end{array}$ & $\begin{array}{l}\text { A. Toledo } \\
(2001-2006)\end{array}$ & $\begin{array}{l}\text { A. Garcia } \\
(2006-2011)\end{array}$ & $\begin{array}{l}\text { O. Humala } \\
\text { (2013-2014) }\end{array}$ & \\
\hline & 31.37 & 35.19 & 40.84 & 52.14 & 47.32 & \\
\hline \multirow{2}{*}{ Venezuela } & $\begin{array}{c}\text { C. Perez } \\
(1989-1993)\end{array}$ & $\begin{array}{l}\text { R. Caldera } \\
(1994-1999)\end{array}$ & $\begin{array}{l}\text { H. Chavez } \\
\text { (1999-2013) }\end{array}$ & $\begin{array}{l}\text { N. Maduro } \\
\text { (2013-2014) }\end{array}$ & & \\
\hline & 56.37 & 49.47 & 50.16 & 54.28 & & \\
\hline \multirow{2}{*}{ Ecuador } & $\begin{array}{l}\text { S.Durán } \\
(1992-1996)\end{array}$ & $\begin{array}{l}\text { J. Mahuad } \\
(1998-2000)\end{array}$ & $\begin{array}{c}\text { G.Noboa } \\
(2000-2003)\end{array}$ & $\begin{array}{l}\text { L. Gutierrez } \\
(2003-2005)\end{array}$ & $\begin{array}{l}\text { A. Palacio } \\
(2005-2007)\end{array}$ & $\begin{array}{c}\text { R. Correa } \\
(2007-2014)\end{array}$ \\
\hline & 44.38 & 44.21 & 50.69 & 53.20 & 51.34 & 59.47 \\
\hline \multirow[t]{2}{*}{ Bolivia } & $\begin{array}{c}\text { J.Paz } \\
(1989-1993)\end{array}$ & $\begin{array}{l}\text { G. Sanchez } \\
(1993-1997)\end{array}$ & $\begin{array}{l}\text { H. Banzer } \\
(1997-2001)\end{array}$ & $\begin{array}{c}\text { C. Mesa } \\
(2003-2005)\end{array}$ & $\begin{array}{c}\text { E. } \\
\text { Rodriguez } \\
(2005-2006)\end{array}$ & $\begin{array}{l}\text { E. Morales } \\
(2006-2014)\end{array}$ \\
\hline & 47.48 & 49.28 & 47.55 & 50.66 & 59.02 & 71.09 \\
\hline
\end{tabular}


Table 6: Average Public External Debt (includes publicly guaranteed debt)

\begin{tabular}{|c|c|c|c|c|c|c|}
\hline \multirow[t]{2}{*}{ Argentina } & $\begin{array}{c}\text { C.S. Menem (1989- } \\
\text { 1999) }\end{array}$ & $\begin{array}{l}\text { R. de la Rúa } \\
\text { (1999-2001) }\end{array}$ & $\begin{array}{l}\text { E. Duhalde } \\
(2001-2003)\end{array}$ & $\begin{array}{l}\text { N. Kirchner } \\
(2003-2007)\end{array}$ & $\begin{array}{l}\text { C. Kirchner } \\
(2007-2014)\end{array}$ & \\
\hline & N.D. & N.D. & N.D. & N.D. & N.D. & \\
\hline \multirow[t]{2}{*}{ Brazil } & $\begin{array}{l}\text { F. Collor (1990- } \\
\text { 1992) }\end{array}$ & $\begin{array}{l}\text { I. Franco } \\
(1992-1994)\end{array}$ & $\begin{array}{l}\text { F. H. Cardoso } \\
(1995-2002)\end{array}$ & $\begin{array}{c}\text { L. I. Lula } \\
(2003-2010)\end{array}$ & $\begin{array}{l}\text { D. Rousseff } \\
\text { (2011-2014) }\end{array}$ & \\
\hline & $18.7 \%$ & $20.3 \%$ & $14.0 \%$ & $8.8 \%$ & $5.4 \%$ & \\
\hline \multirow[t]{2}{*}{ Chile } & $\begin{array}{c}\text { P. Aylwin (1990- } \\
\text { 1994) }\end{array}$ & $\begin{array}{c}\text { E. Frei } \\
(1994-2000)\end{array}$ & $\begin{array}{c}\text { R. Lagos } \\
(2000-2006)\end{array}$ & $\begin{array}{l}\text { M. Bachelet } \\
(2006-2010)\end{array}$ & $\begin{array}{c}\text { S. Piñera } \\
(2010-2013)\end{array}$ & \\
\hline & N.D. & N.D. & N.D. & N.D. & N.D. & \\
\hline \multirow[t]{2}{*}{ Colombia } & $\begin{array}{c}\text { C. Gaviria (1990- } \\
\text { 1994) }\end{array}$ & $\begin{array}{l}\text { E. Samper } \\
(1994-1998)\end{array}$ & $\begin{array}{c}\text { A. Pastrana } \\
(1998-2002)\end{array}$ & $\begin{array}{c}\text { A. Uribe } \\
(2002-2010)\end{array}$ & $\begin{array}{l}\text { J.M. Santos } \\
(2010-2014)\end{array}$ & \\
\hline & $28.3 \%$ & $15.9 \%$ & $20.2 \%$ & $16.1 \%$ & $13.0 \%$ & \\
\hline \multirow[t]{2}{*}{ Mexico } & $\begin{array}{c}\text { C. Salinas (1988- } \\
\text { 1994) }\end{array}$ & $\begin{array}{c}\text { E. Zedillo } \\
(1994-2000)\end{array}$ & $\begin{array}{c}\text { V. Fox } \\
(2000-2006)\end{array}$ & $\begin{array}{c}\text { F. Calderon } \\
(2006-2012)\end{array}$ & $\begin{array}{c}\text { E. Peña } \\
(2006-2014)\end{array}$ & \\
\hline & $22.8 \%$ & $18.2 \%$ & $13.3 \%$ & $13.1 \%$ & $14.2 \%$ & \\
\hline \multirow[t]{2}{*}{ Peru } & $\begin{array}{l}\text { A. Fujimori (1990- } \\
2000)\end{array}$ & $\begin{array}{l}\text { V. Paniagua } \\
(2000-2001)\end{array}$ & $\begin{array}{l}\text { A. Toledo } \\
(2001-2006)\end{array}$ & $\begin{array}{c}\text { A. Garcia } \\
(2006-2011)\end{array}$ & $\begin{array}{l}\text { O. Humala } \\
(2013-2014)\end{array}$ & \\
\hline & $41.3 \%$ & $37.2 \%$ & $34.4 \%$ & $17.2 \%$ & $8.1 \%$ & \\
\hline \multirow[t]{2}{*}{ Venezuela } & $\begin{array}{l}\text { C. Perez (1989- } \\
\text { 1993) }\end{array}$ & $\begin{array}{l}\text { R. Caldera } \\
(1994-1999)\end{array}$ & $\begin{array}{l}\text { H. Chavez } \\
(1999-2013)\end{array}$ & $\begin{array}{l}\text { N. Maduro } \\
(2013-2014)\end{array}$ & & \\
\hline & N.D. & N.D. & N.D. & N.D. & & \\
\hline \multirow[t]{2}{*}{ Ecuador } & $\begin{array}{l}\text { S.Durán (1992- } \\
\text { 1996) }\end{array}$ & $\begin{array}{l}\text { J. Mahuad } \\
(1998-2000)\end{array}$ & $\begin{array}{c}\text { G.Noboa } \\
(2000-2003)\end{array}$ & $\begin{array}{l}\text { L. Gutierrez } \\
(2003-2005)\end{array}$ & $\begin{array}{c}\text { A. Palacio } \\
(2005-2007)\end{array}$ & $\begin{array}{c}\text { R. Correa } \\
\text { (2007-2014) }\end{array}$ \\
\hline & $50.2 \%$ & $57.8 \%$ & $47.4 \%$ & $30.1 \%$ & $23.1 \%$ & $14.3 \%$ \\
\hline \multirow[t]{2}{*}{ Bolivia } & J.Paz (1989-1993) & $\begin{array}{l}\text { G. Sanchez } \\
(1993-1997)\end{array}$ & $\begin{array}{c}\text { H. Banzer } \\
(1997-2001)\end{array}$ & $\begin{array}{c}\text { C. Mesa } \\
(2003-2005)\end{array}$ & $\begin{array}{c}\text { E. } \\
\text { Rodriguez } \\
(2005-2006)\end{array}$ & $\begin{array}{l}\text { E. Morales } \\
(2006-2014)\end{array}$ \\
\hline & $70.6 \%$ & $63.0 \%$ & $49.0 \%$ & $49.9 \%$ & $37.4 \%$ & $16.7 \%$ \\
\hline
\end{tabular}


Table 7: Econometric Results

\begin{tabular}{|c|c|c|c|}
\hline VARIABLES & \multicolumn{3}{|c|}{ GDP Growth } \\
\hline DB Disbursements & $\begin{array}{c}0.995 \\
(2.207)\end{array}$ & & \\
\hline L. DB Disbursements & $\begin{array}{l}-1.016 \\
(2.224)\end{array}$ & & \\
\hline L2. DB Disbursements & $\begin{array}{c}4.496 * * \\
(2.177)\end{array}$ & & \\
\hline IMF Disbursements & & $\begin{array}{l}-3.991 \\
(3.667)\end{array}$ & \\
\hline L. IMF Disbursements & & $\begin{array}{c}5.068 \\
(3.598)\end{array}$ & \\
\hline L2. IMF Disbursements & & $\begin{array}{c}9.697 * * * \\
(3.531)\end{array}$ & \\
\hline Total Disbursements & & & $\begin{array}{l}-0.664 \\
(1.940)\end{array}$ \\
\hline L. Total Disbursements & & & $\begin{array}{c}0.532 \\
(1.903)\end{array}$ \\
\hline L2. Total Disbursements & & & $\begin{array}{c}5.997 * * * \\
(1.847)\end{array}$ \\
\hline Capital Flows & $\begin{array}{l}5.14 \mathrm{e}-05^{*} \\
(3.04 \mathrm{e}-05)\end{array}$ & $\begin{array}{l}5.07 \mathrm{e}-05^{*} \\
(3.05 \mathrm{e}-05)\end{array}$ & $\begin{array}{l}5.15 \mathrm{e}-05^{*} \\
(3.07 \mathrm{e}-05)\end{array}$ \\
\hline To'T & $\begin{array}{c}0.0779 * * \\
(0.0326)\end{array}$ & $\begin{array}{c}0.0839 * * \\
(0.0323)\end{array}$ & $\begin{array}{c}0.0898 * * * \\
(0.0322)\end{array}$ \\
\hline Constant & $\begin{array}{c}-4.171 * \\
(2.492)\end{array}$ & $\begin{array}{c}-4.020^{*} \\
(2.360)\end{array}$ & $\begin{array}{c}-5.732^{* *} \\
(2.582)\end{array}$ \\
\hline Observations & 156 & 156 & 156 \\
\hline R-squared & 0.094 & 0.133 & 0.134 \\
\hline Country Fixed Effect & YES & YES & YES \\
\hline Year Fixed Effect & YES & YES & YES \\
\hline
\end{tabular}

Standard errors in parentheses *** $\mathrm{p}<0.01,{ }^{* *} \mathrm{p}<0.05,{ }^{*} \mathrm{p}<0.1$ 